\title{
Priority sites and conservation gaps of wintering waterbirds in the Yangtze River floodplain
}

\author{
XIA Shaoxia ${ }^{1}$, YU Xiubo ${ }^{1,3}$, LEI Jinyu ${ }^{2}$, HEARN Richard ${ }^{4}$, SMITH Bena ${ }^{4}$, \\ LEI Gang ${ }^{2}$, XIE Ping ${ }^{5}$
}

1. Key Laboratory of Ecosystem Network Observation and Modelling, Institute of Geographic Sciences and Natural Resources Research, CAS, Beijing 100101, China;

2. Living Yangtze Program, World Wide Fund for Nature China, Wuhan 430060, China;

3. College of Resources and Environment, University of Chinese Academy of Sciences, Beijing 100049, China;

4. Wildfowl \& Wetlands Trust, Slimbridge, Gloucestershire GL2 7BT, United Kingdom;

5. State Key Laboratory for Freshwater Ecology and Biotechnology of China, Institute of Hydrobiology, CAS, Wuhan 430072, China

\begin{abstract}
The Yangtze River floodplain is critical for migratory waterbirds along the East Asian-Australasian Flyway (EAAF). Greater awareness of its global importance is urgently needed to ensure waterbird populations remain in favourable conservation status, as well as the enhancement of wider wetland biodiversity within this region. The designation of protected wetland areas and building a green ecological corridor in the Yangtze floodplain is now becoming a critical issue of interest to the Chinese government. Priority sites in this area were identified based on the criteria used to identify sites that qualify as Wetlands of International Importance (Ramsar Sites) and Important Bird and Biodiversity Areas (IBAs) by using multi-source data. The results show that 140 of the sites surveyed are priority sites. The Importance Index (I) for the whole floodplain decreased slightly from 2001-2005 and an unbalanced distribution pattern is evident with Jiangxi and Hunan provinces significantly higher than the other provinces in the floodplain. Although more than $60 \%$ of the priority sites are currently located outside protected areas, the average Conservation Effectiveness Index (C) of the whole floodplain is $75.6 \%$, which suggests the coverage of protected areas for most wintering waterbird population is reasonable. Conservation of the Yangtze River floodplain needs to be further strengthened due to declining waterbird abundances and the mismatch between the distribution of protected areas and their importance for wintering waterbirds. A comprehensive system for priority site identification and protection and scientific review is needed. Multi-sourced data from regular, systematic and coordinated monitoring of waterbird distribution and abundance across the EAAF, as well as national scale citizen science programmes are also critically important.
\end{abstract}

Keywords: wintering waterbirds; Yangtze River floodplain; priority site; feeding guild

Received: 2019-08-05 Accepted: 2020-04-17

Foundation: Strategic Priority Research Program of the Chinese Academy of Sciences, No.XDA23040203; National Natural Science Foundation of China, No.41701212; STS Project of Chinese Academy of Sciences, No.KFJ-SW-YW026

Author: Xia Shaoxia (1983-), Associate Professor, specialized in biodiversity assessment and habitat mapping. E-mail: xiasx@igsnrr.ac.cn 


\section{Introduction}

Habitat loss and degradation are the most pertinent causal factors driving rapid biodiversity decline globally (Rodrigues et al., 2004; Hoekstra et al., 2005). Today, biodiversity conservation action has shifted focus from specific species protection to habitat protection (Hoekstra et al., 2005). The protected area approach is one of the most effective measures currently available to minimize habitat loss and degradation (Chape et al., 2005). A strategically designed nature conservation plan requires a site prioritization system to be in place, so that the limited resources available to maintain ecosystem functions and biodiversity can be deployed to the maximum effect (Bonn and Gaston, 2005; Freudenberger et al., 2013). Such nature conservation plans can also connect science and decision-making concerning ecosystem conservation and management (Vohland et al., 2011; Fu et al., 2017).

Migratory waterbirds include some of the most threatened bird populations in the world, and the identification and protection of key sites and habitats along their flyways has attracted worldwide attention (Kirby et al., 2008; Runge et al., 2015). To effectively maintain waterbird populations, the protected site network should include a complimentary suite of sites that provide for all aspects of the life cycle and daily needs of the species it aspires to protect, e.g. sufficient and available food resources at safe feeding sites and safe shelter (Iwamura et al., 2013; Murray and Fuller, 2015). The Yangtze River floodplain is a globally important region on the East Asian-Australasian Flyway (EAAF) and is estimated to support more than 900,000 wintering waterbirds annually, especially herbivorous Anatidae (Barter et al., 2005). However, the floodplain is under intensive economic and urbanization development pressure (Gao and Zhang, 2010; Gu et al., 2011), resulting in serious conflicts between development and ecological conservation (Cao and Fox, 2009). Habitat degradation, and consequent decreased food availability for waterbirds that feed on tubers and grasses, caused by hydrological regime alterations is also a major issue in this region (Fox et al., 2011; Zhao et al., 2012). The need to balance both conservation and sustainable economic development in the floodplain is urgent. Drawing ecological 'redlines' and planning protected site networks for biodiversity has become an essential part of national strategies related to the Ecological Environmental Protection Plan in the Yangtze River (Yao et al., 2015).

In order to formulate an "ecological redline" for China based on waterbird survey data, a handful of studies have presented the broad situation of waterbirds with relevant information (Cui et al., 2014; Zhang et al., 2017), however it is still necessary to give a comprehensive assessment in this region in order to promote the establishment of a protection network and the wise use of wetlands in a holistic flyway manner which is urgently needed (Margules and Pressey, 2000).

Sufficient species distribution and abundance data are essential for the effective identification of key habitats, yet the lack of such data is a long-standing barrier to the setting up of conservation plans globally (Tantipisanuh and Gale, 2018). In recent decades, citizen science data have filled some of the data gaps and now play an increasingly important role in biodiversity assessments and conservation, especially data from birdwatchers. 'Big data', such as eBird (www.ebird.org.cn) (Sullivan et al., 2009; Snall et al., 2011) and Birdwatching in China (Li et al., 2013; Hu et al., 2017), have made valuable contributions to avian conservation studies. Contemporary methods used to assess and design protected area networks depend on data availability at appropriate spatial scales. MARXAN (Heiner et al., 
2011) and C-plan (Cowling et al., 2003) are more suited to large-scale assessments and heavily rely on occurrence data rather than species abundance data (Manel et al., 2001). Biodiversity mapping using Geographic Information Systems (GIS) has also been used at local and regional scales (Stralberg et al., 2011; Kordi and O'Leary, 2016) and both species richness and occurrence data play important roles when scoring and setting priorities (Bonn and Gaston 2005; Ambal et al., 2012). The latter may provide scientific information to conserve target species, e.g. such data were used to determine the key regions for biodiversity conservation in the Yellow Sea (Mackinnon et al., 2012) and along China's coast (Xia et al., 2017a). In addition, waterbirds in the same 'feeding guild' usually possess similar habitat preferences and exhibit similar feeding characteristics (Kear, 2005). For example, grass eaters typically prefer wet meadow and relatively short swards (Guan et al., 2016), while many shorebirds and dabbling ducks prefer shallow water (Ma et al., 2010). Different guilds may respond differently to changes in habitat variables, such as ecological and anthropogenic factors (Tavares et al., 2015; Zhang et al., 2018). Using 'feeding guild' as a unit to identify core habitats and plan protected areas may be a cost effective approach for policy makers.

In this study, waterbird survey data from coordinated surveys and birdwatchers' records in the Yangtze River floodplain were used to identify priority sites for conservation based on a standardized framework. The importance of individual priority sites is quantified and a spatio-temporal distribution of waterbird importance is mapped. This study supports the provision of a scientific foundation for waterbird conservation and strategic planning in the Yangtze River floodplain.

\section{Data and methodology}

\subsection{Study area}

The Middle and Lower Yangtze floodplain (MLY), with a wetland area of $7.7 \times 10^{6}$ ha, accounts for $17 \%$ of the gross wetland area in China (SFA, 2014). It is one of the most densely distributed lake clusters in China, stretching over 1,000 km inland from the Yangtze estuary at Shanghai and spanning five other provinces, namely, Jiangsu, Anhui, Jiangxi, Hubei and Hunan. The floodplain wetlands primarily consist of shallow lakes, and include globally important waterbodies such as Poyang Lake and Dongting Lake. In total, there are more than 600 lakes with areas greater than $1 \mathrm{~km}^{2}$, representing $37.2 \%$ of the total area of freshwater lakes in China (Wang and Dou, 1998). At present, the total area of provincial and national nature reserves intended to protect wetlands and waterbirds in the Yangtze River floodplain is $2.07 \times 10^{6}$ ha, which accounts for $26.1 \%$ of the total wetland area $\left(7.7 \times 10^{6}\right.$ ha; SFA, 2014) of the region. Sixteen National Nature Reserves make up $39.1 \%$ of the total protected area. There are also 38 Provincial Nature Reserves, accounting for a further $42.4 \%$ of the total protected area, and 57 other nature reserves, making up $18.5 \%$ of the total protected area (China's Nature Reserve specimen resource sharing platform, http://www.papc.cn/). These protected areas include ten Ramsar Sites which are designated to protect waterbirds and their habitats: (1) East, (2) South and (3) West Dongting Lake in Hunan, (4) Poyang Lake National Nature Reverse and (5) Nanji Wetland National Nature Reverse in Jiangxi, (6) Chongming Dongtan in Shanghai, (7) Honghu Lake, (8) Chenhu Lake and (9) Wanghu Lake in Hubei and (10) Shengjin Lake in Anhui (RCS, 2010; https://www.ramsar.org/wetland/ 
china). It is also a priority region of the East Asian-Australasian Flyway Partnership (EAAFP) (Cao et al., 2009) (Figure 1).

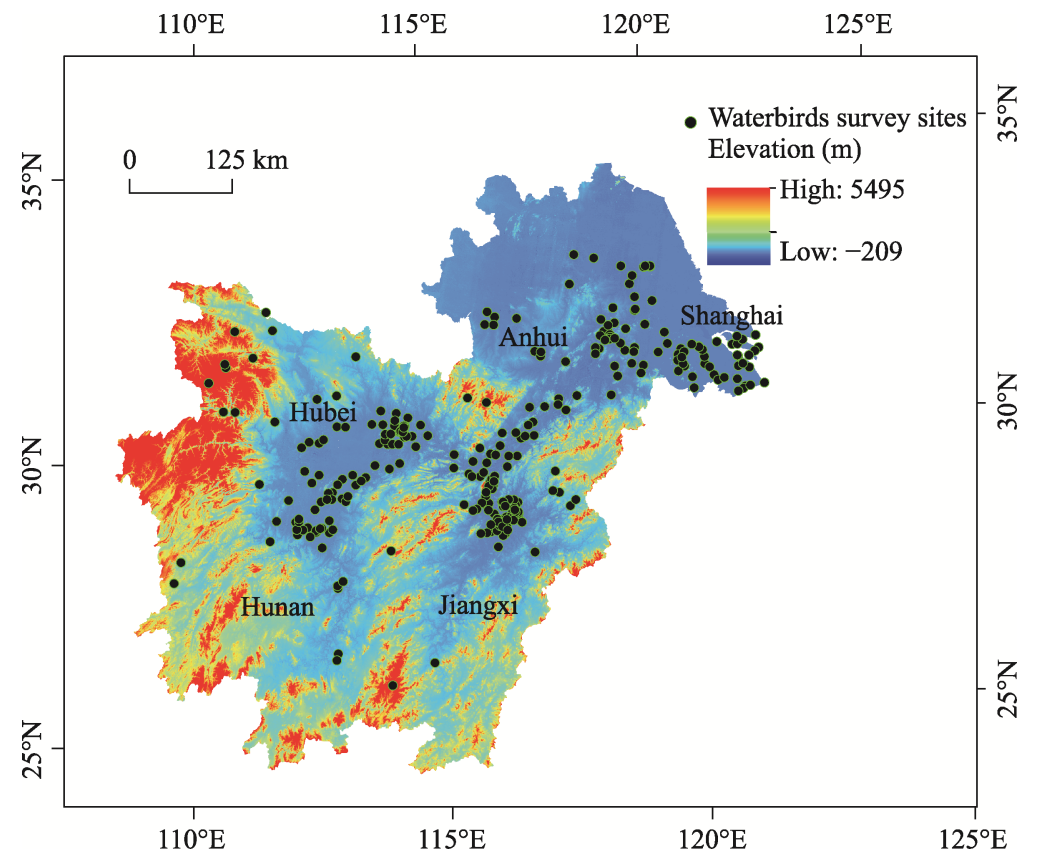

Figure 1 The location of waterbird survey sites in the Yangtze River floodplain

\subsection{Data collection and processing}

Most data used in this study are sourced from coordinated waterbird surveys undertaken in the MLY floodplain in 2004 (Barter et al., 2005), 2005 (Barter et al., 2006), 2011 (Lei et al., 2011 ) and 2015 (Tao et al., 2015). In addition, in order to comprehensively map species distributions over different decades, we combined waterbird data collected before the $2000 \mathrm{~s}$, which were mostly obtained from the literature and site surveys, such as waterbird research in China (Waterbird Specialist Group of Chinese Ornithological Association, 1994) and the Status of Waterbirds in Asia 1987-2007 (Li et al., 2009). Citizen science data, such as the annual China Bird Report (2003-2007) and bird survey records from the China Bird Watching Network website (2008-2015; http:// www.chinabirdnet.org/) were also combined in this study. Wintering waterbirds typically start arriving at the MLY in October and do not depart until the following March, thus waterbird records during this period were used in this study. The dataset includes waterbird species, site name, site location (latitude and longitude), number of individuals and the survey date. Coordinated waterbird surveys in some large areas are usually divided into different counting units according to, e.g., a physical geographic boundary or a specific survey boundary. At Poyang Lake, sub-lakes such as Hanchi Lake and Zhuhu Lake which are separated from Poyang Lake in winter and the Ramsar site, Poyang Lake National Nature Reserve were treated as individual survey units (or sites). Thus, some large areas were divided into several sites and survey data were analysed at the survey unit scale to compare between sites. The dataset contains 15,700 records of 89 species from 309 sites. The waterbird survey sites were located by latitude and longitude using ArcGIS 10.5 and then mapped. Information on protected areas within the MLY 
floodplain, including location data, was collected from China's Nature Reserve specimen resource sharing platform (http://www.papc.cn/).

Identifying priority sites using feeding guild as a determinant, rather than single species, may provide more meaningful information for policy makers and managers to promote conservation activities (Zhang et al., 2018). Therefore in this study, we have classified the waterbird species in the MLY floodplain into five such guilds according to their main foraging habitats and diets (Wang et al., 2013; Appendix A provides a complete species list). The five guilds were: (i) tuber eaters (seven species, including cranes and swans that inhabit shallow water and wet mudflats), (ii) short grass foragers (six geese species that inhabit wet meadows), (iii) seed and aquatic vegetation eaters (18 species, mainly dabbling ducks that inhabit shallow water), (iv) invertebrate eaters (33 species, mainly shorebirds that inhabit muddy areas and the shallowest water), and (v) fish eaters (25 species including storks, egrets and herons).

\subsection{Criteria and thresholds for identifying priority sites and the conservation status of the Middle and Lower Yangtze floodplain for waterbirds}

The criteria and population thresholds used to identify priority sites in the MLY floodplain are shown in Table 1, which refers to the identification criteria for Ramsar Sites (RCS, 2010), and Important Bird and Biodiversity Areas (IBA, Fishpool and Evans, 2001). Sites which met at least one Ramsar or IBA identification criteria were considered as priority sites (criterion listed in Table 1).

Table 1 Criteria and thresholds for identifying priority sites of the Yangtze River floodplain for the conservation of wintering waterbirds

\begin{tabular}{|c|c|c|}
\hline Criteria & Source & Thresholds for identifying priority sites \\
\hline $\begin{array}{l}\text { Criterion } 1 \\
\text { Sites in which a globally threatened } \\
\text { species occurs in significant numbers }\end{array}$ & $\begin{array}{l}\text { Criterion } 2 \text { for identifying Ramsar sites } \\
\text { (Ramsar Convention Secretariat, 2010); } \\
\text { Criterion A1 to determine Important } \\
\text { Bird Area (Fishpool and Evans, 2001) }\end{array}$ & $\begin{array}{l}\text { Regular presence of a single individual } \\
\text { for Critically Endangered (CR) and En- } \\
\text { dangered (EN) species; presence of } 30 \\
\text { individuals for Vulnerable species (VU) } \\
\text { according to IUCN Red List category }\end{array}$ \\
\hline $\begin{array}{l}\text { Criterion } 2 \\
\text { Sites that hold a significant propor- } \\
\text { tion of the flyway population }\end{array}$ & $\begin{array}{l}\text { Criterion } 6 \text { for identifying Ramsar sites } \\
\text { (Ramsar Convention Secretariat, 2010); } \\
\text { Criterion A4 to determine Important } \\
\text { Bird Area (Fishpool and Evans, 2001) }\end{array}$ & $\begin{array}{l}\text { Population exceeds } 1 \% \text { of flyway popu- } \\
\text { lation (hereafter Ramsar } 1 \% \text { criterion) }\end{array}$ \\
\hline $\begin{array}{l}\text { Criterion } 3 \\
\text { Sites that support a significant ag- } \\
\text { gregation of individual waterbirds }\end{array}$ & $\begin{array}{l}\text { Criterion } 5 \text { for identifying Ramsar sites } \\
\text { (Ramsar Convention Secretariat, 2010) }\end{array}$ & Supports 20,000 or more waterbirds \\
\hline
\end{tabular}

Note: The value of Criterion 2 means the percentage of the global or EAAF population published in Waterbird Population Estimates Fifth Edition (Ramsar Convention Secretariat, 2010; WPE5; Wetlands International, 2015; http://wpe. wetlands.org/).

The Importance Index (I) (Xia et al., 2017a) was used to quantify the relative priority of sites (Equation 1). It can also indicate a site's importance and conservation value. A higher value of I represents a higher priority of a site for conservation:

$$
I=\sum_{i=1}^{s} n_{i} / N
$$

where $n_{i}$ denotes the population of the $i t h$ waterbird species at the survey site, $N$ denotes the flyway population of the $i$ th species, according to Waterbird Population Estimates Fifth Edition (WPE5) (Wetlands International, 2015), and $s$ denotes the number of species at the site. 
We also established a Conservation Effectiveness Index $(C)$ to quantify the relative degree of protected area coverage, which was the proportion of the Importance Index under protection, calculated as Equation 2:

$$
\begin{gathered}
C=C_{p} / C_{t} \\
C_{p}=\sum_{i=1}^{s} I_{p} ; C_{t}=\sum_{i=1}^{n} I_{t}
\end{gathered}
$$

where $C_{p}$ denotes the sum of the importance indices of the sites under protection by provincial and national nature reserves in the MLY floodplain or specific provinces. $C_{t}$ denotes the sum of the importance indices of all the sites in the MLY floodplain or specific provinces. Higher $C$ index indicates the main waterbirds or their habitats were under protection.

\subsection{Data processing, priority setting and gap analysis}

Globally threatened species were identified according to the International Union for Conservation of Nature and Natural Resources (IUCN) Red List (http://www.iucnredlist.org/). The peak counts of each species per site were used to identify whether or not a species met the Ramsar 1\% criterion. The average total count of waterbirds during the 2011-2015 period at each site was used to determine the sites' waterbird abundance. The importance of each site was quantified using the Importance Index, determined from Equation 1. The peak count of each species in different provinces/regions (Jiangxi, Hunan, Hubei, Anhui, Jiangsu and Shanghai) or time periods (1980-2000, 2001-2005, 2006-2010 and 2011-2015) was used when we calculate their Importance Index. This was then summarized according to province or time period as the total Importance Index, which may indicate the overall waterbird abundance. A list of protected areas in the MLY floodplain and their locations was collected from the China's Nature Reserve specimen resource sharing platform (http://www.papc.cn/). Most vector files of the boundaries of the protected areas were sourced from Resource and Environment Data Cloud Platform, Chinese Academy of Sciences (http://www.resdc.cn/ data.aspx?DATAID=272), while others were vectorized manually. Individual priority sites were then overlain with the protected areas distribution map. Sites outside the protected areas were network recognized as gap areas.

\section{Results}

\subsection{Priority sites in the Middle and Lower Yangtze floodplain}

Waterbird data from 309 sites throughout the MLY floodplain were analyzed. Overall, 140 sites (45\% of the total) were identified as priorities, 120 of which (39\% of the total) supported at least one species listed as globally threatened on IUCN's Red List). In total, 13 globally threatened species were recorded (Table 2), including two Critically Endangered species (CR), three Endangered species (EN), and eight Vulnerable species (VU).

One hundred and fifteen sites (37\% of the total) met the Ramsar 1\% criterion, and eight of these sites (namely Poyang Lake NNR, Nanji wetland NNR, Duchang PNR, Zhuhu Lake and Dalianzi Lake in Jiangxi; East Dongting Lake NNR in Hunan, Shengjin Lake NNR in Anhui, Chenhu Lake in Hubei) had more than 15 species which met the $1 \%$ criterion. Twenty-seven sites ( $8 \%$ of the total) supported 5000 or more waterbirds and seven sites supported 20,000 or more waterbirds (criterion 3). 
Table 2 Globally threatened waterbirds in the Yangtze River floodplain

\begin{tabular}{lllc}
\hline \multicolumn{1}{c}{ English name } & \multicolumn{1}{c}{ Scientific name } & IUCN category & $\begin{array}{c}\text { Number of sites where the } \\
\text { species was present during the } \\
\text { wintering season }\end{array}$ \\
\hline Baer's Pochard & Aythya baeri & CR & 38 \\
Siberian Crane & Grus leucogeranus & CR & 49 \\
Far Eastern Curlew & Numenius madagascariensis & EN & 13 \\
Oriental Stork & Ciconia boyciana & EN & 71 \\
Scaly-sided Merganser & Mergus squamatus & EN & 9 \\
Common Pochard & Aythya ferina & VU & 48 \\
Dalmatian Pelican & Pelecanus crispus & VU & 9 \\
Hooded Crane & Grus monacha & VU & 31 \\
Horned Grebe & Podiceps auritus & VU & 7 \\
Lesser White-fronted Goose & Anser erythropus & VU & 33 \\
Saunders's Gull & Larus saundersi & VU & 28 \\
Swan Goose & Anser cygnoides & VU & 73 \\
White-naped Crane & Grus vipio & VU & 28 \\
\hline
\end{tabular}

In total, 140 sites met either the Ramsar criteria or IBA criteria, while only 10 of these sites of them are currently designated as Ramsar sites and 54 are identified as or included in IBAs (Appendix B). The spatial distribution of these sites is shown in Figure 2. Eight sites have an Importance Index of more than 200, namely Poyang Lake NNR, Duchang PNR, East Dongting Lake NNR, Nanji wetland NNR, Zhuhu Lake, Shengjin Lake, Longgan Lake and Hanchi Lake, while 12 sites with an Importance Index between 100 to 200, and seven
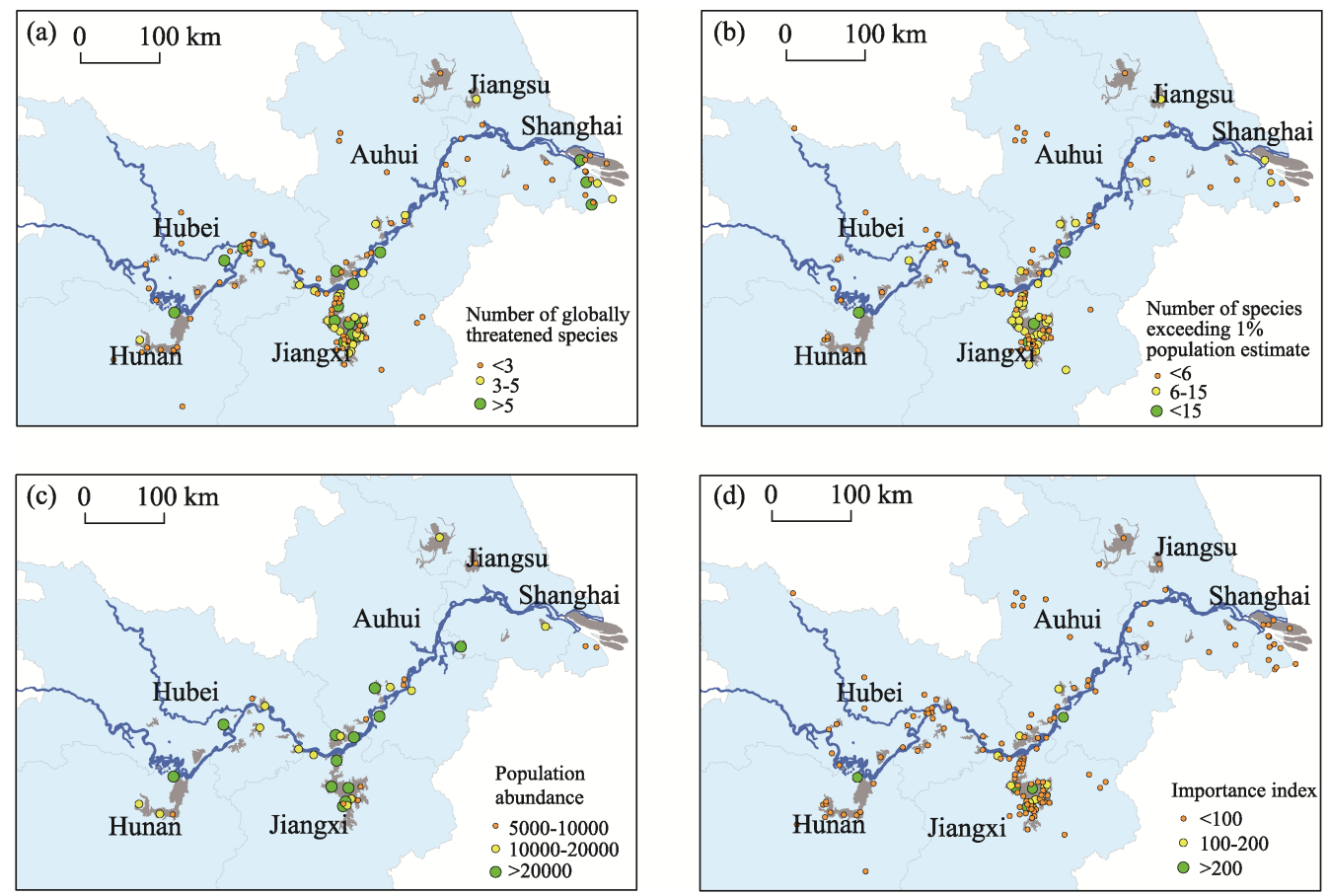

Figure 2 Sites with (a) globally threatened species, (b) species meeting the Ramsar 1\% criterion, (c) high total waterbird abundance, and (d) high Importance Index 
sites between 50 to 100 . The sites are listed according to their Importance Index value in Appendix B.

\subsection{Spatio-temporal variation of waterbird conservation values in the Yangtze River floodplain}

The total Importance Index values from various time periods (1980-2000, 2001-2005, 2006-2010 and 2011-2015) were calculated to present waterbirds abundance changes, as well as waterbirds spatial patterns in the MLY floodplain (Figure 3). The results showed that the Importance Index of the whole floodplain decreased slightly from 2001-2005 to 2011-2015, which is suggestive of a decrease in total waterbird abundance during this period. The Importance Index was also low before 2000, however this is likely to be an underestimate due to data limitations. The overall spatial pattern is asymmetric. Jiangxi Province, with 62 priority sites, stands out as the most prominent region for waterbird conservation. Its Importance Index is twice the sum of the other regions, which collectively hold 78 priority sites.
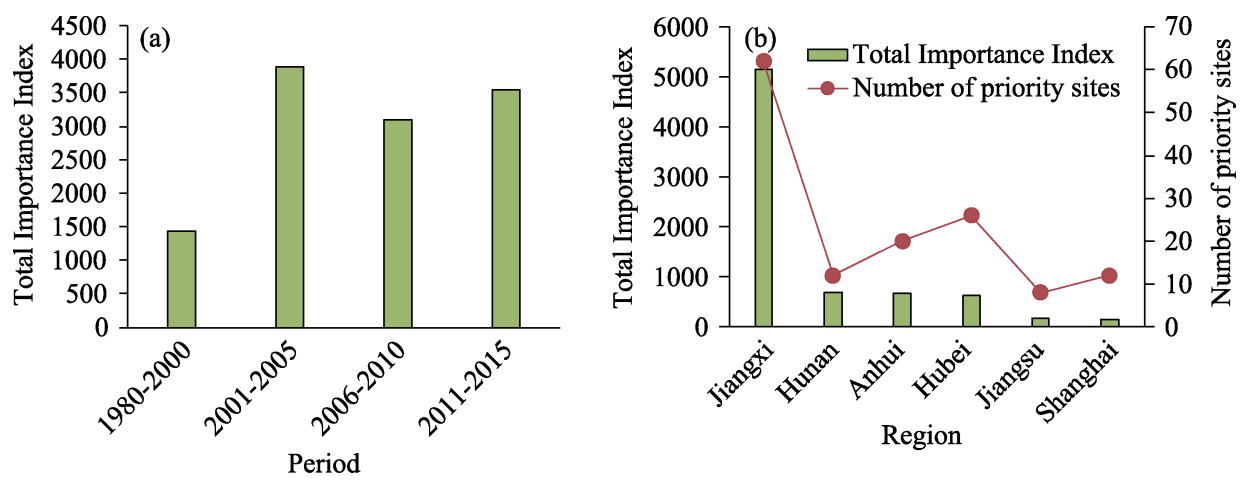

Figure 3 Spatio-temporal variations of Importance Index in the Yangtze River floodplain

\subsection{Importance Index for different waterbird feeding guilds in the Yangtze River floodplain}

We also analyzed the spatial patterns of the Importance Index for various feeding guilds. The results of this analysis show that waterbirds are most dependent on wetland habitats in Jiangxi Province, which had the highest Importance Index for all five feeding guilds (Figure 4). Notably, it accounted for more than $50 \%$ of the total Importance Index for tuber eaters and invertebrate eaters, and more than $40 \%$ for seed eaters and fish eaters. Hunan and Anhui accounted for $38 \%$ and $15 \%$, respectively, for grass eaters. Hunan and Shanghai accounted for nearly $20 \%$ of seed eaters.

\subsection{Conservation Effectiveness Index and gaps in the Yangtze River floodplain}

The total protected areas in MLY floodplain is $2.07 \times 10^{6}$ ha, which account for $26.1 \%$ of the total wetland areas in this region; most are natural wetlands. After comparative analysis with the distribution of protected areas, we found that 87 of the 140 priority sites $(62.1 \%)$ identified in this study are located outside of the current protected area network in the MLY. 

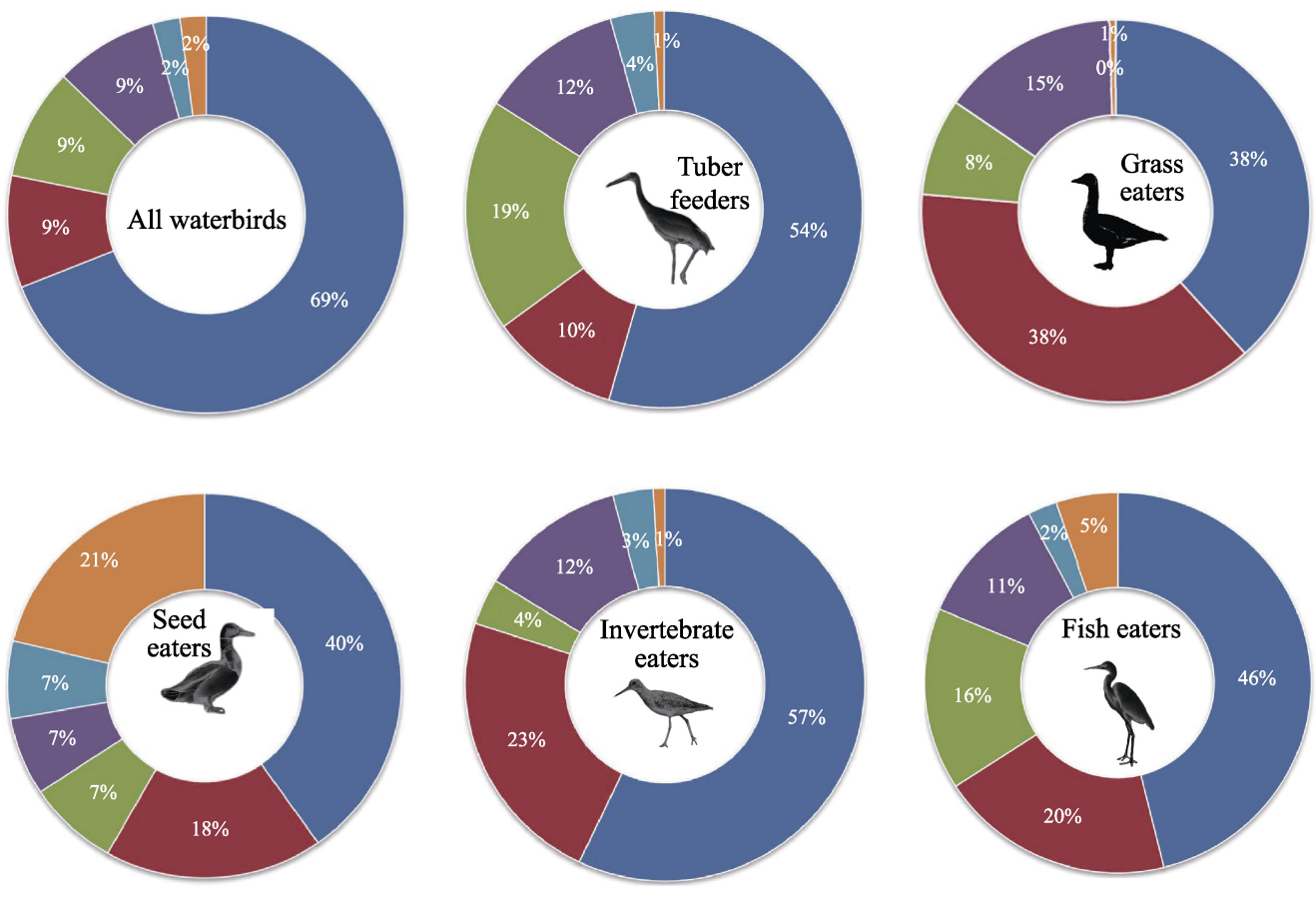

$$
\text { Jiangxi Hunan Hubei Anhui } \square \text { Shanghai Jiangsu }
$$

Figure 4 The proportion of the Importance Index in different provinces for five feeding guilds

The status of protected area coverage, along with the size of the protected areas in each region of the MLY, is shown in Table 3. Overall, we found a relatively high $C$ index in the MLY with an average value of $75.6 \%$. Anhui and Hunan had the highest $C$ index values (98.3\% and $97.5 \%$, respectively), meaning most of the important waterbird sites in those provinces are legally protected. Hubei and Jiangsu, with $C$ indices of about $80 \%$ (Hubei $84.6 \%$ and Jiangsu 79.1\%), also have relatively high levels of legal protection. Jiangxi, however, has a relatively low $C$ index (69.1\%) despite its high Importance Index (twice the total sum of all other provinces). Shanghai had the lowest $C$ index (56.9\%). We can build new protected areas or expand the land areas of existing protected areas to cover all priorities sites to fill conservation gaps, this may however be unrealistic to implement.

Table 3 Protected areas and conservation effectiveness indices in the Yangtze River floodplain

\begin{tabular}{lccccccc}
\hline \multicolumn{1}{c}{ Items (Regions) } & Anhui & Hubei & Hunan & Jiangsu & Jiangxi & Shanghai & MLY \\
\hline Number of suevey sites & 32 & 71 & 43 & 64 & 78 & 21 & 309 \\
Total Importance Index & 672.44 & 610.66 & 677.87 & 154.27 & 5142.45 & 152.19 & 7409.88 \\
$\begin{array}{l}\text { Importance Index of sites being } \\
\text { protected }\end{array}$ & 661.22 & 516.69 & 660.72 & 121.98 & 3557.17 & 86.66 & 5604.44 \\
Protected area (10 $0^{3}$ ha) & 328.51 & 289.44 & 485.64 & 533.47 & 341.94 & 93.88 & 2072.88 \\
$\begin{array}{l}\text { Proportion of protected area to } \\
\text { wetland area (\%) }\end{array}$ & 31.5 & 20.0 & 47.6 & 18.9 & 34.6 & 20.2 & 26.90 \\
Conservation gap rate (\%) & 30.0 & 52.0 & 58.3 & 62.5 & 75.8 & 75.0 & 62.10 \\
Conservation Effectiveness Index (\%) & 98.3 & 84.6 & 97.5 & 79.1 & 69.1 & 56.9 & 75.63 \\
\hline
\end{tabular}


To strengthen the protected area network in the MLY, we suggest enhancing the conservation effectiveness by increasing the total Importance Index value for protection and assigning a greater priority to sites with high individual importance values. After further analysis, six sites are proposed as the best for increasing the $C$ index in the whole MLY to more than $85 \%$ (Figure 5). The analysis showed that this could be achieved solely by selecting six sites in Jiangxi, namely Dalianzi Lake, Linchong Lake, Qihu Lake, Chihu Lake, Chengjiachi and Dawu Lake suggesting Jiangxi Province should be the focus when developing a blueprint for a stronger protected area network in the MLY.

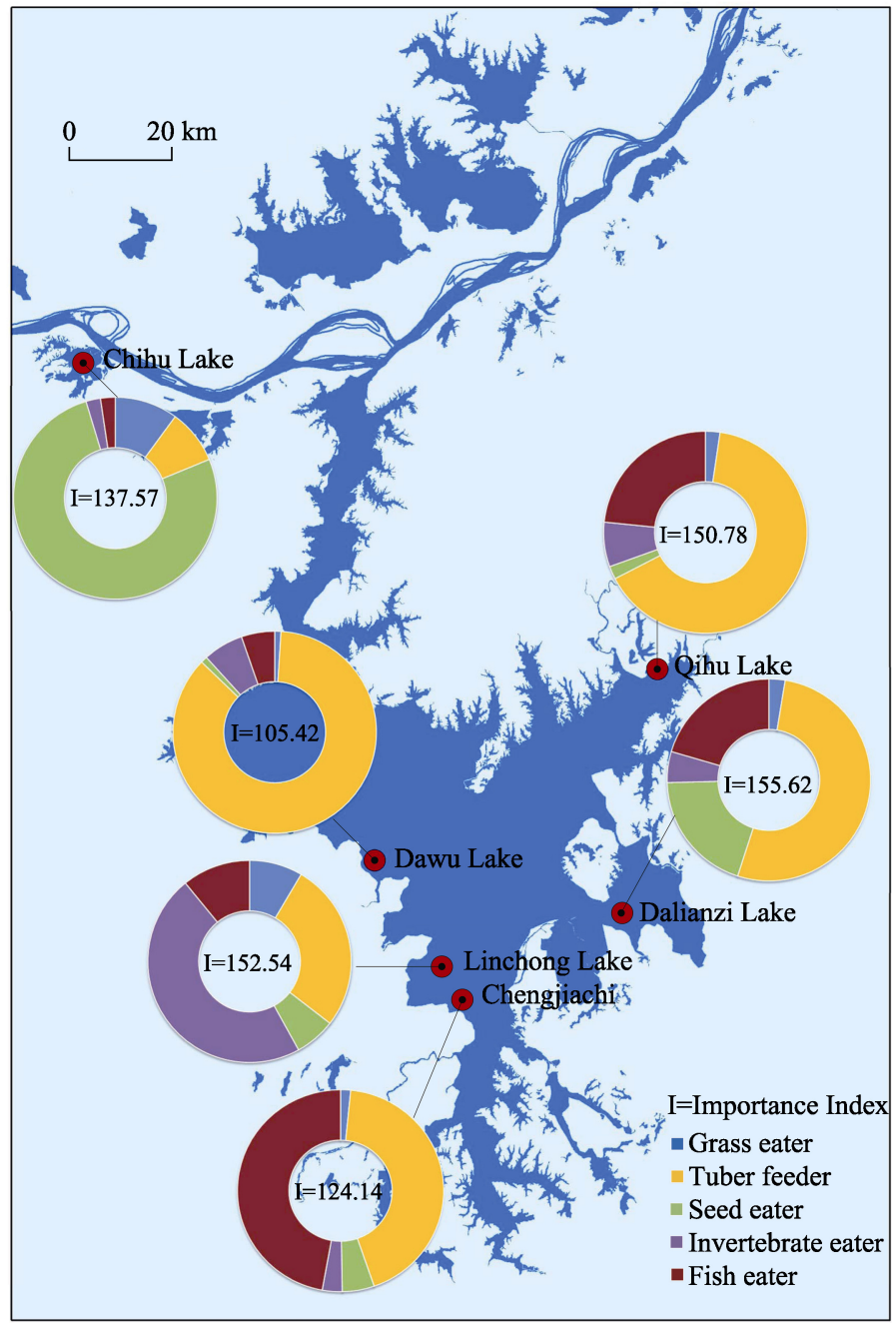

Figure 5 Priority sites proposed for the establishment of new protected areas in Jiangxi Province

\section{Discussion}

\subsection{Conservation assessment methods in this study}

A spatial prioritization method was applied in this study, and wetland priorities, as well as 
the $C$ index in the Yangtze River floodplain were determined from waterbird survey data obtained from multiple sources. Internationally accepted criteria and standards were used to identify sites qualified as Important Bird and Biodiversity Areas (IBA; Fishpool and Evans, 2001) or wetlands of international importance (RCS, 2010). We referred to the assessment framework and data processing procedures in Xia et al. (2017a). C index is an important indicator for the most effective and efficient design of protected area networks. In previous studies, the extent of site protection is usually measured through conservation gap rates, that is the ratio of unprotected sites (numbers or areas) to the total sites (numbers or areas) (Xia et al., 2017a). However, when calculated in this way, it may not fully represent the rationale of why protected areas are needed and, therefore, may not be an appropriate guide for the planning of protected area networks. To investigate ways to improve on this, we evaluated the conservation efforts using a slightly different approach which gives a more ecologically meaningful result. We calculated the $C$ index as the ratio of the sum of the Importance Index of sites covered by protected areas to the total Importance Index in the region. A higher $C$ index means that a greater proportion of all waterbirds in a region occur at protected sites. We introduced the concept of 'feeding guild' into the identification of priority sites, rather than only focusing on individual species. The dynamics of feeding guilds inherently implies there is variation in habitat types in these areas. Feeding guilds can also help guide future management options within protected areas by recognizing that habitat 'ownership' based on clarifying the requirements of specific feeding guilds, promotes habitat conservation activities through a cost-effective way (Zhang et al., 2018).

Citizen science data and coordinated waterbird survey data were compiled in this study to maximize the accuracy and comprehensiveness of the results. Coordinated waterbird survey data are only available after 2004 in the MLY River and such waterbird survey data, supported by WWF and WWT, from 2004, 2005, 2011 and 2015 were the main data source in this study. Citizen science data (e.g. China Birdwatching Association, CBA) were particularly useful for identifying occurrences of globally threatened species. In the future, we anticipate that a large quantity of data will be generated through citizen-science approaches and rigorous data validation processes will be required during data collation and any follow-up studies (Cohn, 2008). The criteria for Ramsar Sites and Important Bird and Biodiversity Areas state that the site should 'regularly' support more than $1 \%$ of the population or 20,000 or more individuals. We used the average number of individuals in 2011 and 2015 when assessing the population abundance for individual sites, since no other recent synchronously collected data were available. For some species, the peak count from a single survey was used to calculate the Importance Index. These peak count values were verified by bird experts or local investigators to ensure reliable results. The observed increase in conservation values from 1980-2000 to 2001-2005 should be treated with a degree of caution, since systematic and insufficient data before 2000 may lead to underestimation. In addition, we focus on wintering waterbirds, particularly Anatidae, along the EAAF and most of the data are sourced from coordinated surveys during mid-winter. The Yangtze Estuary, e.g. Chongming Dongtan in Shanghai, is an important stop over site for shorebirds on migration in spring and autumn, hence its conservation value may be an underestimated by this study. Furthermore, we suggest that future coordinated surveys in MLY should be expanded to in- 
clude migration periods (spring and autumn) so that the importance of each site for stop over migratory waterbirds is better understood, which in turn can ensure a more comprehensive and better managed protected area network is developed.

\subsection{Policy implication on waterbirds and their habitats conservation}

Waterbirds along the EAAF faithfully utilize a number of traditional wintering sites and studies have shown that the MLY floodplain has been a long-standing wintering habitat for waterbirds along the flyway since at least the 1960s (Cao et al., 2009). Our study suggested that the total Importance Index in the MLY floodplain declined after 2001-2005, which implies that waterbird abundance is decreasing in this region due to declines in some waterbird populations in the EAAF. However, what cannot be ignored is that as habitat degradation occurs elsewhere in China, the MLY floodplain becomes more and more critical for wintering waterbirds if they cannot find alternative habitats.

Meanwhile, the study also showed that there are 140 sites met either Ramsar or IBA criteria or both, while only ten of them are designated as Ramsar sites and 54 of them identified as or included in current IBAs, which indicates that the value of the MLY floodplain is currently underestimated.

Furthermore, this study also highlighted the unbalanced distribution pattern in the MLY. Jiangxi and Hunan account for almost $60 \%$ of the Importance Index for all five feeding guilds. For tuber eaters and invertebrate eaters, they account for in excess of $70 \%$ (Figure 4 ). The spatial distribution of these waterbirds, which was wide in historical periods, is beginning to show a more concentrated pattern, partly because of reduced seasonal inundation as a result of dams affecting hydrological regimes (Wang et al., 2017; Xia et al., 2017b). Moreover, a mismatch between the locations of protected areas and the provincial conservation values cannot be ignored; Jiangxi Province, which has the highest conservation value, has a relatively low $C$ index (Table 3 ) in turn can ensure a more comprehensive and better managed protected area network is developed. Nevertheless, wetland conservation across the whole floodplain still needs to be further strengthened along with its important role in the flyway and potential habitat degradation in the MLY floodplain.

Scientific conservation planning coupled with effective governance is essential to achieve successful waterbird conservation (Brooks et al., 2006; Amano et al., 2018). Currently, protection of the Yangtze River floodplain has the attention of the Chinese central government who advocated 'the integrated conservation of the Yangtze River' in early 2016. How to allocate protected wetland areas and build a green ecological corridor is now becoming a critical issue. The approach to identify priority sites for waterbirds provides a useful example. For successful conservation planning, a comprehensive system for key habitat identification including regular review and adaptation is necessary (William et al., 2016). Waterbird habitats in the MLY floodplain have undergone dramatic changes due to factors such as climate change, habitat loss/degradation and operation of the Three Gorges Dam. The formulation of a comprehensive basin-scale conservation plan should consider the above factors, whilst having a regular review process in the future. For example, we suggest enhancing conservation and management on some sub-lakes in Poyang Lake and Dongting Lake, which have hydrological interactions with the Yangtze River during the wet season and are inde- 
pendent systems in the dry season. Some of these sub-lakes are already identified as important sites for waterbirds, and it is therefore easier to undertake habitat management and restoration action. However, we acknowledge that this method is based on protection at the site level, and building a protected network of wetlands flyway-wide is more important. Therefore, we should connect waterbird conservation efforts in the MLY floodplain with that of the EAAF network. Firstly, it is necessary to undertake regular systematic and coordinated monitoring at the flyway and national level. In addition, whilst flyway waterbird population estimates directly affect the evaluation of a site's importance, the accuracy of these population estimates varies considerably from species to species. For some species, e.g. Siberian Crane Grus leucogeranus, the population estimate is quite accurate, whereas the estimated population size or population trend of Common Coot Fulica atra is quite coarse or even non-existent. Therefore, organizing internationally coordinated monitoring for all waterbird species to understand population trends, support flyway population estimates and facilitate the setting of the population $1 \%$ criterion should be urgently strengthened. Furthermore, the value and use of data collected outside of coordinated surveys (e.g. citizen science data) should also be enhanced. For example, collect as much information as possible about species distribution, as well as population trend through citizen science data to complete the protected area networks especially for the identification of important waterbird sites at all periods of the annual life cycle. To improve the overall quality and accuracy of related studies, it is vital to strengthen capacity on data integration, setting standards for multi-source data collection, collation and quality control. Furthermore, economic factors rather than conservation values tend to influence local governments when setting the location and boundaries of protected areas, which has had an adverse impact on biodiversity (Zhao et al., 2013; Ma et al., 2019). Although the situation in MLY floodplain is acceptable, there is an unbalanced pattern with low conservation indices in Jiangxi and Shanghai. Therefore, we propose that conservation planning and the process of setting areas and boundaries for protected areas should be led by central government with local government involvement. This would optimize the allocation of conservation resources, improve the efficacy of protection and circumnavigate local government desire for economic development.

\section{Conclusions}

This paper establishes a framework and roadmap for biodiversity assessment based on conservation priority by using wintering waterbirds as an indicator. We proposed the use of Conservation Effectiveness Index $(C)$ rather than protected rate to generate more meaningful information.

The main findings of this study are as follows:

The Importance Index of the entire Yangtze River floodplain has decreased slightly from 2001-2005 which implies a decline in overall waterbird abundance, while the spatial pattern of Importance Index in the region is unbalanced; more than $60 \%$ of the priority sites are currently located outside protected areas; we therefore recommend further strengthening of the protected area network to better protect declining and internationally important waterbird 
populations; six sites are the priority for protected status, namely Dalianzi Lake, Linchong Lake, Qihu Lake, Chihu Lake, Chengjiachi and Dawu Lake as their designation increase the total Importance Index (I) be protected in the MLY to $85 \%$.

This study provides support to the implementation and planning of the ecological 'redline' along the Yangtze River, as well as the construction of the Yangtze River Ecological Corridor.

\section{Acknowledgement}

We sincerely thank WWF-China, the Wildfowl \& Wetlands Trust (WWT), HSBC, CocaCola, UPS, and Bird report in China for supporting data collection.

\section{References}

Amano T, Szekely T, Sandel B et al., 2018. Successful conservation of global waterbird populations depends on effective governance. Nature, 553(7687): 199-202.

Ambal R, Duya M, Cruz M et al., 2012. Key biodiversity areas in the Philippines: Priorities for conservation. Journal of Threatened Taxa, 4(8): 2788-2796.

Barter M, Lei G, Cao L, 2005. Waterbird Survey of the Middle and Lower Yangtze River Floodplain (February 2004). Beijing: China Forestry Publishing House.

Barter M, Lei G, Cao L, 2006. Waterbird Survey of the Middle and Lower Yangtze River Floodplain (February 2005). Beijing: China Forestry Publishing House.

Waterbird Specialist Group of Chinese Ornithological Association, 1994. Waterbird Research in China. Shanghai: East China Normal University Press.

Bonn A, Gaston K J, 2005. Capturing biodiversity: Selecting priority areas for conservation using different criteria. Biodiversity and Conservation, 14(5): 1083-1100.

Brooks T, Mittermeier R, Da Fonseca G et al., 2006. Global biodiversity conservation priorities. Science, 313(5783): 58-61.

Cao L, Fox A D, 2009. Birds and people both depend on China's wetlands. Nature, 460(7252): $173-173$.

Cao L, Tang S, Wang X et al., 2009. The importance of eastern China for shorebirds during the non-breeding season. Emu, 109(2): 170-178.

Cao L, Zhang Y, Barter M et al., 2010. Anatidae in eastern China during the non-breeding season: Geographical distributions and protection status. Biological Conservation, 143(3): 650-659.

Chape S, Harrison J, Spalding M et al., 2005. Measuring the extent and effectiveness of protected areas as an indicator for meeting global biodiversity targets. Philosophical Transactions of the Royal Society B, 360(1454): $443-455$.

Cohn J P, 2008. Citizen science: Can volunteers do real research? BioScience, 58(3): 192-197.

Cowling R M, Pressey R L, Rouget M et al., 2003. A conservation plan for a global biodiversity hotspot - the Cape Floristic Region, South Africa. Biological Conservation, 112(1/2): 191-216.

Cui P, Wu Y, Ding H et al., 2014. Status of wintering waterbirds at selected locations in China. Waterbirds, 37(4): 402-409.

Fishpool L, Evans M, 2001. Important Bird Areas (IBA) in Africa and associated islands: Priority sites for conservation. Cambridge, UK: BirdLife International (Conservation Series No.11).

Fox A D, Cao L, Zhang Y et al., 2011. Declines in the tuber-feeding waterbird guild at Shengjin Lake National Nature Reserve, China: A barometer of submerged macrophyte collapse. Aquatic Conservation: Marine and Freshwater Ecosystems, 21(1): 82-91. 
Freudenberger L, Hobson P, Schluck M et al., 2013. Nature conservation: Priority-setting needs a global change. Biodiversity and Conservation, 22(5): 1255-1281.

Fu B J, Yu D D, Lu N, 2017. Indicator system for biodiversity and ecosystem services evaluation in China. Acta Ecologica Sinica, 37(2): 341-348. (in Chinese)

Gao C, Zhang T L, 2010. Eutrophication in a Chinese context: Understanding various physical and socio-economic aspects. Ambio, 39(5/6): 385-393.

$\mathrm{Gu}$ C, Hu L, Zhang X et al., 2011. Climate change and urbanization in the Yangtze River Delta. Habitat International, 35(4): 544-552.

Guan L, Lei J L, Zuo A J et al., 2016. Optimizing the timing of water level recession for conservation of wintering geese in Dongting Lake, China. Ecological Engineering, 88: 90-98.

Heiner M, Higgins J, Li X H et al., 2011. Identifying freshwater conservation priorities in the upper Yangtze River Basin. Freshwater Biology, 56(1): 89-105.

Hoekstra J M, Boucher T M, Ricketts T H et al., 2005. Confronting a biome crisis: Global disparities of habitat loss and protection. Ecology Letters, 8(1): 23-29.

Hu R, Wen C, Gu Y et al., 2017. A bird's view of new conservation hotspots in China. Biological Conservation, 211: 47-55.

Iwamura T, Possingham H P, Chades I et al., 2013. Migratory connectivity magnifies the consequences of habitat loss from sea-level rise for shorebird populations. Proceedings of the Royal Society B Biological Sciences, 280(1761): 20130325.

Kear J, 2005. Ducks, Geese and Swans: Species Accounts (Cairina to Mergus). Oxford: Oxford University Press.

Kirby J S, Stattersfield A J, Butchart S H M et al., 2008. Key conservation issues for migratory land- and waterbird species on the world's major flyways. Bird Conservation International, 18(Suppl.1): S49-S73.

Kordi M N, O’Leary M, 2016. A spatial approach to improve coastal bioregion management of the north western Australia. Ocean \& Coastal Management, 127: 26-42.

Lei G, Lei J Y, Tao X et al., 2011. Report on waterbird survey of the Middle and Lower Yangtze in 2011. In: Living Yangtze Program, World Wide Fund for Nature China.

Li X Y, Liang L, Gong P et al., 2013. Bird watching in China reveals bird distribution changes. Chinese Science Bulletin, 58(6): 649-656.

Li Z W D, Mundkur T, Bakewell D et al., 2009. Status of waterbirds in Asia: Results of the Asian waterbird census, 1987-2007. Wetlands International Kuala Lumpur, Malaysia.

Ma Z J, Cai R, Li R et al., 2010. Managing wetland habitats for waterbirds: An international perspective. Wetlands, 2010, 30(1): 15-27.

Ma Z J, Chen Y, Melville D S et al., 2019. Changes in area and number of nature reserves in China. Conservation Biology, 33(5): 1066-1075.

Mackinnon J, Verkuil Y I, Murray N, 2012. IUCN situation analysis on East and Southeast Asian intertidal habitats, with particular reference to the Yellow Sea (including the Bohai Sea). Occasional Paper of the IUCN Species Survival Commission 47.

Manel S, Williams H C, Ormerod S J, 2001. Evaluating presence-absence models in ecology: The need to account for prevalence. Journal of Applied Ecology, 38(5): 921-931.

Margules C R, Pressey R L, 2000. Systematic conservation planning. Nature, 405: 243-253.

Murray N J, Fuller R A, 2015. Protecting stopover habitat for migratory shorebirds in East Asia. Journal of Ornithology, 156: S217-S225.

Ramsar Convention Secretariat (RCS), 2010. Designating Ramsar sites: Strategic framework and guidelines for the future development of the List of Wetlands of International Importance. 4th ed. Ramsar Handbooks for the Wise Use of Wetlands Vol.17. Ramsar Convention Secretariat, Gland, Switzerland. www.ramsar.org/pdf/lib/ hbk4-17.pdf. 
Rodrigues A S L, Akcakaya H R, Andelman S J et al., 2004. Global gap analysis: Priority regions for expanding the global protected-area network. Bioscience, 54(12): 1092-1100.

Runge C A, Watson J E M, Butchart S H M et al., 2015. Protected areas and global conservation of migratory birds. Science, 350(6265): 1255-1258.

State Forestry Administration (SFA), 2014. The Second Investigation of Wetland Resources in China. http://xzsp.forestry.gov.cn/. (in Chinese)

Snall T, Kindvall O, Nilsson J et al., 2011. Evaluating citizen-based presence data for bird monitoring. Biological Conservation, 144(2): 804-810.

Stralberg D, Cameron D R, Reynolds M D et al., 2011. Identifying habitat conservation priorities and gaps for migratory shorebirds and waterfowl in California. Biodiversity and Conservation, 20(1): 19-40.

Sullivan B L, Wood C L, Iliff M J et al., 2009. eBird: A citizen-based bird observation network in the biological sciences. Biological Conservation, 142(10): 2282-2292.

Tantipisanuh N, Gale G A, 2018. Identification of biodiversity hotspot in national level: Importance of unpublished data. Global Ecology \& Conservation, 13: e00377.

Tao X, Lei J Y, Hearn R et al., 2015. Report on the Coordinated Survey for Wintering Waterbirds of the Central and Lower Yangtze. Beijing: China Forestry Publishing House.

Tavares D C, Guadagnin D L, Moura J F D et al., 2015. Environmental and anthropogenic factors structuring waterbird habitats of tropical coastal lagoons: Implications for management. Biological Conservation, 186: $12-21$.

Vohland K, Mlambo M C, Horta L D et al., 2011. How to ensure a credible and efficient IPBES? Environmental Science \& Policy, 14(8): 1188-1194.

Wang S M, Dou H S, 1998. Lakes in China. Beijing: Science Press. (in Chinese)

Wang W J, Fraser J D, Chen J K, 2017. Wintering waterbirds in the middle and lower Yangtze River floodplain: Changes in abundance and distribution. Bird Conservation International, 27(2): 167-186.

Wang Y, Jia Y, Guan L et al., 2013. Optimising hydrological conditions to sustain wintering waterbird populations in Poyang Lake National Natural Reserve: Implications for dam operations. Freshwater Biology, 58(11): 2366-2379.

Wetlands International, 2015. Waterbird Population Estimates. 5th ed. http://wpe.wetlands.org/.

Williams G, Stroud D A, Hirons G J M et al., 2016. Developing a quantitative index as a pragmatic aid to assessing implementation of European Union Birds Directive site protection measures for individual species. Bird Study, 63(4): 1-12.

Xia S X, Yu X B, Millington S et al., 2017a. Identifying priority sites and gaps for the conservation of migratory waterbirds in China's coastal wetlands. Biological Conservation, 210: 72-82.

Xia S X, Wang Y Y, Lei G et al., 2017b. Restriction of herbivorous waterbird distributions in the middle and lower Yangtze River floodplain in view of hydrological isolation. Wetlands, 37: 79-88.

Zhang L, Wang X, Zhang J J et al., 2017. Formulating a list of sites of waterbird conservation significance to contribute to China's ecological protection red line. Bird Conservation International, 27(2): 153-166.

Zhang Y, Fox A D, Cao L et al., 2019. Effects of ecological and anthropogenic factors on waterbird abundance at a Ramsar Site in the Yangtze River floodplain. Ambio, 48: 293-303.

Zhao G H, Tian Y, Tang Z Y et al., 2013. Distribution of terrestrial national nature reserves in relation to human activities and natural environments in China. Biodiversity Science, 21(6): 658-665. (in Chinese)

Zhao M, Cong P, Barter M et al., 2012. The changing abundance and distribution of Greater White-fronted Geese Anser albifrons in the Yangtze River floodplain: Impacts of recent hydrological changes. Bird Conservation International, 22(2): 135-143. 
Appendix A Feeding guilds and 1\% population thresholds for waterbird species in the Yangtze River floodplain Note: waterbird species population retrieved from Waterbird Population Estimates Fifth edition (Wetland International 2018, wpe.wetlands.org). null= no data

\begin{tabular}{|c|c|c|c|c|}
\hline Feeding guilds & English name & Scientific name & IUCN category & $1 \%$ threshold \\
\hline Grass eaters & Bar-headed Goose & Anser indicus & $\mathrm{LC}$ & 560 \\
\hline Grass eaters & Bean Goose & Anser fabalis & $\mathrm{LC}$ & 1100 \\
\hline Grass eaters & Greater White-fronted Goose & Anser albifrons & $\mathrm{LC}$ & 1800 \\
\hline Grass eaters & Greylag Goose & Anser anser & $\mathrm{LC}$ & 710 \\
\hline Grass eaters & Lesser White-fronted Goose & Anser erythropus & VU & 260 \\
\hline Grass eaters & Snow Goose & Chen caerulescens & $\mathrm{LC}$ & 1 \\
\hline Tuber eaters & Common Crane & Grus grus & $\mathrm{LC}$ & 160 \\
\hline Tuber eaters & Hooded Crane & Grus monacha & VU & 10 \\
\hline Tuber eaters & Siberian Crane & Grus leucogeranus & $\mathrm{CR}$ & 35 \\
\hline Tuber eaters & Swan Goose & Anser cygnoides & VU & 680 \\
\hline Tuber eaters & Tundra Swan & Cygnus columbianus & $\mathrm{LC}$ & 1000 \\
\hline Tuber eaters & White-naped Crane & Grus vipio & VU & 10 \\
\hline Tuber eaters & Whooper Swan & Cygnus cygnus & $\mathrm{LC}$ & 600 \\
\hline Seed / aquatic vegetation & Baikal Teal & Anas formosa & $\mathrm{LC}$ & 7100 \\
\hline Seed / aquatic vegetation & Common Coot & Fulica atra & $\mathrm{LC}$ & 20,000 \\
\hline Seed / aquatic vegetation & Common Moorhen & Gallinula chloropus & $\mathrm{LC}$ & 10,000 \\
\hline Seed / aquatic vegetation & Common Pochard & Aythya ferina & VU & 3000 \\
\hline Seed / aquatic vegetation & Common Teal & Anas crecca & $\mathrm{LC}$ & 7700 \\
\hline Seed / aquatic vegetation & Eurasian Wigeon & Anas penelope & $\mathrm{LC}$ & 7100 \\
\hline Seed / aquatic vegetation & Falcated Teal & Anas falcata & NT & 830 \\
\hline Seed / aquatic vegetation & Ferruginous Duck & Aythya nyroca & NT & 1000 \\
\hline Seed / aquatic vegetation & Gadwall & Anas strepera & $\mathrm{LC}$ & 7100 \\
\hline Seed / aquatic vegetation & Garganey & Anas querquedula & $\mathrm{LC}$ & 1400 \\
\hline Seed / aquatic vegetation & Greater Scaup & Aythya marila & $\mathrm{LC}$ & 2400 \\
\hline Seed / aquatic vegetation & Mallard & Anas platyrhynchos & $\mathrm{LC}$ & 15,000 \\
\hline Seed / aquatic vegetation & Mandarin Duck & Aix galericulata & $\mathrm{LC}$ & 400 \\
\hline Seed / aquatic vegetation & Northern Pintail & Anas acuta & $\mathrm{LC}$ & 2400 \\
\hline $\mathrm{e}$ & Purple Swamphen & Porphyrio porphyrio & $\mathrm{LC}$ & 250 \\
\hline Seed / aquatic vegetation & Ruddy Shelduck & Tadorna ferruginea & $\mathrm{LC}$ & 710 \\
\hline Seed / aquatic vegetation & Spot-billed Duck & Anas poecilorhyncha & $\mathrm{LC}$ & 1000 \\
\hline Seed / aquatic vegetation & Tufted Duck & Aythya fuligula & $\mathrm{LC}$ & 2400 \\
\hline Invertebrate eaters & Water Rail & Rallus aquaticus & $\mathrm{LC}$ & 10,000 \\
\hline Invertebrate eaters & Baer's Pochard & Aythya baeri & $\mathrm{CR}$ & 5 \\
\hline Invertebrate eaters & Common Shelduck & Tadorna tadorna & $\mathrm{LC}$ & 1200 \\
\hline Invertebrate eaters & Black-tailed Godwit & Limosa limosa & NT & 1500 \\
\hline Invertebrate eaters & Black-winged Stilt & Himantopus himantopus & $\mathrm{LC}$ & 1000 \\
\hline
\end{tabular}


(Continued)

\begin{tabular}{|c|c|c|c|c|}
\hline Feeding guilds & English name & Scientific name & IUCN category & $1 \%$ threshold \\
\hline Invertebrate eaters & Common Goldeneye & Bucephala clangula & $\mathrm{LC}$ & 10,000 \\
\hline Invertebrate eaters & Common Greenshank & Tringa nebularia & $\mathrm{LC}$ & 1000 \\
\hline Invertebrate eaters & Common Redshank & Tringa totanus & $\mathrm{LC}$ & 1000 \\
\hline Invertebrate eaters & Common Sandpiper & Actitis hypoleucos & $\mathrm{LC}$ & 500 \\
\hline Invertebrate eaters & Common Snipe & Gallinago gallinago & $\mathrm{LC}$ & 10,000 \\
\hline Invertebrate eaters & Dunlin & Calidris alpina & $\mathrm{LC}$ & 1000 \\
\hline Invertebrate eaters & Eurasian Curlew & Numenius arquata & NT & 1000 \\
\hline Invertebrate eaters & Eurasian Spoonbill & Platalea leucorodia & $\mathrm{LC}$ & 100 \\
\hline Invertebrate eaters & Far Eastern Curlew & Numenius madagascariensis & EN & 320 \\
\hline Invertebrate eaters & Green Sandpiper & Tringa ochropus & $\mathrm{LC}$ & 1000 \\
\hline Invertebrate eaters & Grey Plover & Pluvialis squatarola & $\mathrm{LC}$ & 1000 \\
\hline Invertebrate eaters & Grey-headed Lapwing & Vanellus cinereus & $\mathrm{LC}$ & 1000 \\
\hline Invertebrate eaters & Kentish Plover & Charadrius alexandrinus & $\mathrm{LC}$ & 1000 \\
\hline Invertebrate eaters & Little Ringed Plover & Charadrius dubius & $\mathrm{LC}$ & 250 \\
\hline Invertebrate eaters & Long-billed Plover & Charadrius placidus & $\mathrm{LC}$ & 250 \\
\hline Invertebrate eaters & Marsh Sandpiper & Tringa stagnatilis & $\mathrm{LC}$ & 10,000 \\
\hline Invertebrate eaters & Northern Lapwing & Vanellus vanellus & $\mathrm{LC}$ & 10,000 \\
\hline Invertebrate eaters & Northern Shoveler & Anas clypeata & $\mathrm{LC}$ & 5000 \\
\hline Invertebrate eaters & Pacific Golden Plover & Pluvialis fulva & $\mathrm{LC}$ & 1000 \\
\hline Invertebrate eaters & Pheasant-tailed Jacana & Hydrophasianus chirurgus & $\mathrm{LC}$ & 1200 \\
\hline Invertebrate eaters & Pied Avocet & Recurvirostra avosetta & $\mathrm{LC}$ & 1000 \\
\hline Invertebrate eaters & Pintail Snipe & Gallinago stenura & $\mathrm{LC}$ & 10,000 \\
\hline Invertebrate eaters & Red-necked Stint & Calidis ruficollis & $\mathrm{LC}$ & 3200 \\
\hline Invertebrate eaters & Spotted Redshank & Tringa erythropus & $\mathrm{LC}$ & 250 \\
\hline Invertebrate eaters & Swinhoe's Snipe & Gallinago megala & $\mathrm{LC}$ & 1,000 \\
\hline Invertebrate eaters & Temminck's Stint & Calidris temminckii & $\mathrm{LC}$ & 1,000 \\
\hline Invertebrate eaters & Wood Sandpiper & Tringa glareola & $\mathrm{LC}$ & 1,000 \\
\hline Fish eaters & Black Stork & Ciconia nigra & $\mathrm{LC}$ & 1 \\
\hline Fish eaters & Black-crowned Night Heron & Nycticorax nycticorax & $\mathrm{LC}$ & 1,000 \\
\hline Fish eaters & Black-headed Gull & Larus ridibundus & $\mathrm{LC}$ & 20,000 \\
\hline Fish eaters & Black-necked Grebe & Podiceps nigricollis & $\mathrm{LC}$ & 1000 \\
\hline Fish eaters & Black-tailed Gull & Larus crassirostris & $\mathrm{LC}$ & 10,500 \\
\hline Fish eaters & Cattle Egret & Bubulcus ibis & $\mathrm{LC}$ & 10,000 \\
\hline Fish eaters & Chinese Pond-Heron & Ardeola bacchus & $\mathrm{LC}$ & 10,000 \\
\hline Fish eaters & Common Merganser & Mergus merganser & $\mathrm{LC}$ & 710 \\
\hline Fish eaters & Common Tern & Sterna hirundo & $\mathrm{LC}$ & 9800 \\
\hline Fish eaters & Dalmatian Pelican & Pelecanus crispus & VU & 1 \\
\hline Fish eaters & Eurasian Bittern & Botaurus stellaris & $\mathrm{LC}$ & 1000 \\
\hline
\end{tabular}


(Continued)

\begin{tabular}{|c|c|c|c|c|}
\hline Feeding guilds & English name & Scientific name & IUCN category & $1 \%$ threshold \\
\hline Fish eaters & Great Cormorant & Phalacrocorax carbo & $\mathrm{LC}$ & 1000 \\
\hline Fish eaters & Great Crested Grebe & Podiceps cristatus & $\mathrm{LC}$ & 350 \\
\hline Fish eaters & Great Egret & Egretta alba & $\mathrm{LC}$ & 1000 \\
\hline Fish eaters & Grey Heron & Ardea cinerea & $\mathrm{LC}$ & 10,000 \\
\hline Fish eaters & Horned Grebe & Podiceps auritus & VU & 250 \\
\hline Fish eaters & Intermediate Egret & Ardea intermedia & $\mathrm{LC}$ & 1000 \\
\hline Fish eaters & Little Egret & Egretta garzetta & $\mathrm{LC}$ & 10,000 \\
\hline Fish eaters & Little Grebe & Tachybptus ruficollis & $\mathrm{LC}$ & 1000 \\
\hline Fish eaters & Mew Gull & Larus canus & $\mathrm{LC}$ & 2900 \\
\hline Fish eaters & Oriental Stork & Ciconia boyciana & EN & 30 \\
\hline Fish eaters & Red-necked Grebe & Podiceps grisegena & $\mathrm{LC}$ & 450 \\
\hline Fish eaters & Saunders's Gull & Larus saundersi & VU & 85 \\
\hline Fish eaters & Scaly-sided Merganser & Mergus squamatus & $\mathrm{EN}$ & 50 \\
\hline Fish eaters & Smew & Mergellus albellus & $\mathrm{LC}$ & 250 \\
\hline
\end{tabular}

Appendix B Identified priority sites for waterbird conservation in the Yangtze River floodplain Note: $\mathrm{NNR}=$ National Nature Reserve, $\mathrm{PNR}=$ Provincial Nature Reserve, NR=Other Nature Reserve, WP= Wetland Park, UN-unprotected. *=Ramsar site and \#=included in Important Bird Areas

\begin{tabular}{|c|c|c|c|c|c|c|c|c|c|c|c|}
\hline \multirow[b]{2}{*}{ No. } & \multirow[b]{2}{*}{ Region } & \multirow[b]{2}{*}{ Site name } & \multirow[b]{2}{*}{ Latitude } & \multirow[b]{2}{*}{$\begin{array}{l}\text { Lon- } \\
\text { gitude }\end{array}$} & \multirow[b]{2}{*}{$\begin{array}{c}\text { Protected } \\
\text { area } \\
\text { status }\end{array}$} & \multirow[b]{2}{*}{$\begin{array}{l}\text { Impor- } \\
\text { tance } \\
\text { Index }\end{array}$} & \multirow[b]{2}{*}{$\begin{array}{l}\text { Tuber } \\
\text { eaters }\end{array}$} & \multicolumn{3}{|c|}{ Feeding guilds } & \multirow[b]{2}{*}{$\begin{array}{c}\text { Fish } \\
\text { eaters }\end{array}$} \\
\hline & & & & & & & & $\begin{array}{l}\text { Grass } \\
\text { eaters }\end{array}$ & $\begin{array}{l}\text { Seed and } \\
\text { aquatic } \\
\text { vegetation } \\
\text { eaters }\end{array}$ & $\begin{array}{c}\text { Inver- } \\
\text { tebrate } \\
\text { eaters }\end{array}$ & \\
\hline 1 & Jiangxi & $\begin{array}{l}\text { Poyang Lake } \\
\text { NNR*\# }\end{array}$ & 29.18 & 116.01 & NNR & 1235.50 & 465.97 & 168.91 & 99.57 & 314.15 & 186.90 \\
\hline 2 & Jiangxi & Duchang PNR\# & 29.14 & 116.35 & PNR & 522.31 & 170.50 & 90.47 & 109.79 & 104.68 & 46.87 \\
\hline 3 & Hunan & $\begin{array}{l}\text { East Dongting } \\
\text { Lake NNR*\# }\end{array}$ & 29.48 & 112.80 & NNR & 515.02 & 95.78 & 167.35 & 87.94 & 130.54 & 33.41 \\
\hline 4 & Jiangxi & $\begin{array}{l}\text { Nanji wetland } \\
\text { NNR*\# }\end{array}$ & 28.83 & 116.22 & NNR & 443.89 & 126.58 & 47.55 & 56.28 & 170.78 & 42.70 \\
\hline 5 & Jiangxi & Zhuhu Lake\# & 29.15 & 116.60 & UN & 356.14 & 123.89 & 8.05 & 86.41 & 26.24 & 111.55 \\
\hline 6 & Anhui & $\begin{array}{l}\text { Shengjin } \\
\text { Lake*\# }\end{array}$ & 30.35 & 117.08 & NNR & 280.10 & 103.25 & 58.73 & 28.12 & 43.56 & 46.44 \\
\hline 7 & $\begin{array}{l}\text { Hubei/ } \\
\text { Anhui }\end{array}$ & Longgan Lake\# & 30.08 & 116.15 & PNR & 249.25 & 170.67 & 19.99 & 3.89 & 4.98 & 49.72 \\
\hline 8 & Jiangxi & Hanchi Lake\# & 28.95 & 116.39 & UN & 234.42 & 161.89 & 9.12 & 3.24 & 18.46 & 41.71 \\
\hline 9 & Jiangxi & Dalianzi Lake\# & 28.91 & 116.53 & UN & 155.62 & 81.55 & 4.00 & 30.50 & 7.74 & 31.83 \\
\hline 10 & Jiangxi & Baishazhou\# & 29.20 & 116.65 & NR & 153.87 & 95.33 & 7.54 & 13.40 & 23.62 & 13.98 \\
\hline 11 & Jiangxi & Sanhu Lake\# & 28.91 & 116.27 & NR & 153.35 & 23.47 & 4.03 & 1.85 & 80.61 & 43.39 \\
\hline 12 & Jiangxi & $\begin{array}{l}\text { Linchong } \\
\text { Lake\# }\end{array}$ & 28.83 & 116.29 & UN & 152.54 & 41.21 & 12.93 & 9.92 & 71.90 & 16.58 \\
\hline 13 & Jiangxi & Qihu Lake\# & 28.77 & 116.40 & UN & 150.79 & 98.15 & 3.48 & 3.14 & 10.73 & 35.29 \\
\hline 14 & Jiangxi & Chihu Lake\# & 29.75 & 115.68 & UN & 137.57 & 11.98 & 13.81 & 105.27 & 3.29 & 3.22 \\
\hline 15 & Jiangxi & $\begin{array}{l}\text { Nanhu Lake } \\
\text { (in Gongqing)\# }\end{array}$ & 29.22 & 115.91 & NR & 135.20 & 103.88 & 0.06 & 0.56 & 16.24 & 14.46 \\
\hline 16 & Jiangxi & Chengjiachi\# & 28.81 & 116.33 & UN & 124.14 & 53.57 & 1.95 & 6.25 & 3.84 & 58.53 \\
\hline 17 & Jiangxi & Saicheng Lake & 29.46 & 116.14 & NR & 122.25 & 52.92 & 10.53 & 48.85 & 3.96 & 5.99 \\
\hline
\end{tabular}


(Continued)

\begin{tabular}{|c|c|c|c|c|c|c|c|c|c|c|c|}
\hline \multirow[b]{2}{*}{ No. } & \multirow[b]{2}{*}{ Region } & \multirow[b]{2}{*}{ Site name } & \multirow[b]{2}{*}{$\begin{array}{l}\text { Lati- } \\
\text { tude }\end{array}$} & \multicolumn{4}{|c|}{ Feeding guilds } & \multirow[b]{2}{*}{$\begin{array}{l}\text { Grass } \\
\text { eaters }\end{array}$} & \multirow[b]{2}{*}{$\begin{array}{c}\text { Seed and } \\
\text { aquatic } \\
\text { vegetation } \\
\text { eaters }\end{array}$} & \multirow[b]{2}{*}{$\begin{array}{c}\text { Inver- } \\
\text { tebrate } \\
\text { eaters }\end{array}$} & \multirow[b]{2}{*}{$\begin{array}{c}\text { Fish } \\
\text { eaters }\end{array}$} \\
\hline & & & & $\begin{array}{l}\text { Longi- } \\
\text { tude }\end{array}$ & $\begin{array}{c}\text { Pro- } \\
\text { tected } \\
\text { area } \\
\text { status }\end{array}$ & $\begin{array}{c}\text { Impor- } \\
\text { tance } \\
\text { Index }\end{array}$ & $\begin{array}{l}\text { Tuber } \\
\text { eaters }\end{array}$ & & & & \\
\hline 18 & Anhui & Caizi Lake\# & 30.85 & 117.03 & PNR & 115.04 & 52.26 & 7.70 & 5.09 & 38.58 & 11.41 \\
\hline 19 & Jiangsu & Gaoyou Lake\# & 32.86 & 119.35 & NR & 106.36 & 1.62 & 2.42 & 95.80 & 3.37 & 3.15 \\
\hline 20 & Jiangxi & Dawu Lake\# & 29.02 & 116.15 & UN & 105.43 & 90.93 & 1.05 & 1.10 & 6.76 & 5.59 \\
\hline 21 & Hubei & Chenhu Lake*\# & 30.36 & 113.86 & PNR & 98.90 & 4.19 & 19.49 & 24.49 & 18.81 & 31.92 \\
\hline 22 & Hunan & $\begin{array}{l}\text { West Dongting } \\
\text { Lake*\# }\end{array}$ & 29.02 & 112.08 & PNR & 93.05 & 1.40 & 1.08 & 9.00 & 4.02 & 77.55 \\
\hline 23 & Jiangxi & Nanjiang Lake\# & 28.95 & 116.48 & UN & 86.02 & 50.46 & 4.95 & 0.80 & 1.89 & 27.92 \\
\hline 24 & Jiangxi & Zhouxi Lake\# & 29.21 & 116.05 & $\mathrm{UN}$ & 83.72 & 42.75 & 24.37 & 10.00 & 6.08 & 0.52 \\
\hline 25 & Shanghai & $\begin{array}{l}\text { Chongming } \\
\text { Dongtan*\# }\end{array}$ & 31.23 & 121.47 & NNR & 80.06 & 32.91 & 0.12 & 25.07 & 15.37 & 6.59 \\
\hline 26 & Jiangxi & Kangshan Lake\# & 28.89 & 116.58 & NR & 79.15 & 45.12 & 1.99 & 0.41 & 8.05 & 23.58 \\
\hline 27 & Hubei & Wang Lake* & 29.87 & 115.38 & PNR & 60.55 & 4.55 & 3.28 & 22.95 & 8.45 & 21.32 \\
\hline 28 & Jiangxi & Jinxi Lake\# & 28.66 & 116.35 & UN & 43.48 & 36.51 & 0.69 & 2.95 & 3.00 & 0.33 \\
\hline 29 & $\begin{array}{l}\text { Jiangsu/ } \\
\text { Anhui }\end{array}$ & Shijiu Lake\# & 31.45 & 118.88 & PNR & 41.23 & 7.07 & 12.97 & 2.39 & 17.00 & 1.80 \\
\hline 30 & Anhui & Huanghu Lake & 30.02 & 116.52 & PNR & 41.09 & 5.24 & 29.50 & 1.63 & 0.14 & 4.58 \\
\hline 31 & Jiangxi & Qinglan Lake & 28.43 & 116.20 & NR & 40.80 & 7.77 & 2.53 & 26.14 & 2.27 & 2.09 \\
\hline 32 & Jiangxi & Chenjia Lake\# & 28.66 & 116.35 & UN & 40.55 & 26.87 & 0.25 & 5.55 & 5.66 & 2.22 \\
\hline 33 & Hubei & Hannan Lake & 30.63 & 114.38 & UN & 40.55 & 0.31 & 1.49 & 28.11 & 0.28 & 10.36 \\
\hline 34 & Jiangxi & Nanbeigang Lake\# & 29.68 & 116.21 & UN & 40.19 & 0.93 & 0.92 & 1.60 & 15.35 & 21.39 \\
\hline 35 & Anhui & Bohu Lake & 30.21 & 116.36 & PNR & 39.35 & 0.23 & 2.30 & 0.52 & 18.31 & 17.99 \\
\hline 36 & Anhui & Wuchang Lake & 30.32 & 116.80 & PNR & 38.67 & 10.60 & 23.80 & 1.53 & 0.30 & 2.44 \\
\hline 37 & Jiangxi & $\begin{array}{l}\text { Yugan Nanhu } \\
\text { Lake }\end{array}$ & 28.80 & 116.26 & UN & 35.35 & 26.61 & 0.97 & 2.75 & 3.15 & 1.87 \\
\hline 38 & Jiangxi & $\begin{array}{l}\text { Yugan Donghu } \\
\text { Lake }\end{array}$ & 28.30 & 116.93 & UN & 35.08 & 28.37 & 0.55 & 0.83 & 4.09 & 1.24 \\
\hline 39 & Jiangxi & Boyang Lake & 29.63 & 116.20 & UN & 34.54 & 2.44 & 1.50 & 1.24 & 23.73 & 5.63 \\
\hline 40 & Hubei & Dongxi Lake & 30.56 & 114.26 & UN & 30.91 & 0.67 & 6.06 & 2.16 & 6.30 & 15.72 \\
\hline 41 & Jiangxi & Luojiao Lake\# & 29.09 & 116.04 & UN & 30.54 & 17.81 & 6.76 & 2.26 & 0.64 & 3.07 \\
\hline 42 & Hunan & Hengling Lake & 28.82 & 112.76 & PNR & 29.86 & 0.14 & 1.14 & 12.31 & 6.44 & 9.83 \\
\hline 43 & Anhui & Fengsha Lake & 30.96 & 117.65 & PNR & 29.36 & 18.16 & 0.33 & 8.05 & 1.21 & 1.61 \\
\hline 44 & Jiangxi & Duchang Xi Lake\# & 29.25 & 116.47 & UN & 29.21 & 5.67 & 3.12 & 3.82 & 15.40 & 1.20 \\
\hline 45 & Jiangxi & Fanghu Lake\# & 29.83 & 116.48 & NR & 29.10 & 11.00 & 7.65 & 5.20 & 3.01 & 2.24 \\
\hline 46 & Anhui & Baidang Lake & 30.84 & 117.34 & PNR & 28.90 & 11.39 & 4.11 & 2.06 & 10.99 & 0.35 \\
\hline 47 & Jiangxi & Junshan Lake\# & 28.63 & 116.30 & UN & 27.53 & 15.59 & 0.72 & 5.34 & 0.57 & 5.31 \\
\hline 48 & Jiangxi & Xieshan Lake\# & 29.63 & 116.14 & UN & 26.40 & 3.49 & 10.84 & 0.20 & 4.79 & 7.08 \\
\hline 49 & Jiangxi & Qili Lake & 29.69 & 115.91 & UN & 25.77 & 1.57 & 1.58 & 3.87 & 0.57 & 18.18 \\
\hline 50 & Jiangxi & Taibo Lake & 30.01 & 116.70 & NR & 25.61 & 5.56 & 4.19 & 9.42 & 4.68 & 1.76 \\
\hline 51 & Jiangxi & Liaohuachi & 29.34 & 116.00 & NR & 25.43 & 8.81 & 0.92 & 4.52 & 3.97 & 7.21 \\
\hline 52 & Jiangxi & Gaoqiang Lake & 29.53 & 116.17 & UN & 25.13 & 1.27 & 6.67 & 13.86 & 3.19 & 0.14 \\
\hline 53 & Hubei & Liangzi Lake & 30.28 & 114.61 & PNR & 25.04 & 3.28 & 0.15 & 13.50 & 1.55 & 6.56 \\
\hline
\end{tabular}


(Continued)

\begin{tabular}{|c|c|c|c|c|c|c|c|c|c|c|c|}
\hline \multirow[b]{2}{*}{ No. } & \multirow[b]{2}{*}{ Region } & \multirow[b]{2}{*}{ Site name } & \multirow[b]{2}{*}{$\begin{array}{l}\text { Lati- } \\
\text { tude }\end{array}$} & \multicolumn{4}{|c|}{ Feeding guilds } & \multirow[b]{2}{*}{$\begin{array}{l}\text { Grass } \\
\text { eaters }\end{array}$} & \multirow[b]{2}{*}{$\begin{array}{l}\text { Seed and } \\
\text { aquatic } \\
\text { vegetation } \\
\text { eaters }\end{array}$} & \multirow[b]{2}{*}{$\begin{array}{l}\text { Inver- } \\
\text { tebrate } \\
\text { eaters }\end{array}$} & \multirow[b]{2}{*}{$\begin{array}{l}\text { Fish } \\
\text { eaters }\end{array}$} \\
\hline & & & & $\begin{array}{l}\text { Lon- } \\
\text { gitude }\end{array}$ & $\begin{array}{c}\text { Protected } \\
\text { area } \\
\text { status }\end{array}$ & $\begin{array}{l}\text { Impor- } \\
\text { tance } \\
\text { Index }\end{array}$ & $\begin{array}{l}\text { Tuber } \\
\text { eaters }\end{array}$ & & & & \\
\hline 54 & Jiangxi & $\begin{array}{l}\text { Wuxing- } \\
\text { kenzhichang }\end{array}$ & 28.72 & 116.18 & UN & 20.86 & 20.86 & & & & \\
\hline 55 & Jiangsu & Shang Lake & 31.65 & 120.68 & UN & 20.78 & & & 3.67 & 0.18 & 16.93 \\
\hline 56 & Jiangxi & Yufeng & 28.87 & 116.23 & UN & 20.00 & & & & & 20.00 \\
\hline 57 & Shanghai & $\begin{array}{l}\text { Hengsha } \\
\text { Dongtan }\end{array}$ & 31.63 & 121.39 & UN & 19.57 & & 0.01 & 5.14 & 10.27 & 4.15 \\
\hline 58 & Jiangxi & Zaohu Lake\# & 29.59 & 116.19 & UN & 18.69 & 1.03 & 1.30 & 1.37 & 8.58 & 6.41 \\
\hline 59 & Jiangxi & Meixi Lake\# & 29.51 & 116.07 & UN & 17.52 & 11.16 & 1.35 & 0.98 & 2.10 & 1.93 \\
\hline 60 & Hunan & $\begin{array}{l}\text { South Dongting } \\
\text { Lake*\# }\end{array}$ & 28.83 & 112.50 & PNR & 17.11 & 1.51 & 0.79 & 10.30 & 1.59 & 2.92 \\
\hline 61 & Anhui & Daguan Lake & 30.05 & 116.25 & PNR & 16.42 & 2.47 & 7.04 & 1.56 & 1.02 & 4.33 \\
\hline 62 & Hubei & Chong Lake & 29.91 & 112.29 & UN & 15.17 & & & 13.86 & 1.18 & 0.13 \\
\hline 63 & Jiangxi & $\begin{array}{l}\text { Embankment in } \\
\text { Shuanggang Town }\end{array}$ & 29.03 & 116.59 & UN & 15.08 & 0.01 & & & 0.06 & 15.01 \\
\hline 64 & Shanghai & Nanhui Dongtan\# & 30.88 & 121.97 & UN & 14.78 & 0.03 & 0.01 & 3.83 & 8.93 & 1.98 \\
\hline 65 & Jiangsu & Hongze Lake\# & 33.37 & 118.63 & PNR & 14.25 & 5.56 & & 8.62 & & 0.07 \\
\hline 66 & Hubei & Donghu Lake & 30.56 & 114.37 & UN & 13.34 & 6.82 & & 0.03 & 0.09 & 6.40 \\
\hline 67 & Jiangxi & Nanshan Lake\# & 31.78 & 118.58 & UN & 12.38 & 8.30 & 0.27 & 0.67 & 0.20 & 2.94 \\
\hline 68 & Hubei & $\begin{array}{l}\text { Shishoutian'e } \\
\text { zhou\# }\end{array}$ & 29.70 & 112.43 & NNR & 11.80 & 0.12 & 0.08 & 0.56 & 2.91 & 8.13 \\
\hline 69 & Hubei & Zhangdu Lake & 30.65 & 114.73 & NR & 11.38 & 0.04 & 0.56 & 5.58 & 1.78 & 3.42 \\
\hline 70 & Jiangxi & Liufang Lake\# & 28.93 & 116.21 & UN & 10.59 & & & 0.02 & & 10.57 \\
\hline 71 & Anhui & Shibasuo & 30.76 & 117.78 & PNR & 10.52 & 0.40 & 0.60 & 2.59 & 0.02 & 6.91 \\
\hline 72 & Jiangxi & Caowan Lake\# & 28.84 & 116.30 & UN & 10.51 & 0.15 & 9.93 & 0.41 & 0.01 & 0.01 \\
\hline 73 & Hubei & Honghu Lake*\# & 29.82 & 113.28 & PNR & 10.05 & & 2.16 & 4.38 & 0.85 & 2.66 \\
\hline 74 & Anhui & Tangduo Lake & 32.47 & 116.42 & PNR & 9.40 & 9.40 & & & & \\
\hline 75 & Hunan & Qingtanyuan & 28.87 & 112.84 & UN & 8.93 & 0.01 & 0.04 & 0.11 & 0.42 & 8.35 \\
\hline 76 & Shanghai & Baogangshuiku & 31.41 & 121.49 & UN & 8.55 & & & 5.08 & 3.13 & 0.34 \\
\hline 77 & Jiangxi & Jiujiang Lake\# & 29.70 & 115.74 & UN & 8.28 & 6.01 & 1.09 & 0.19 & & 0.99 \\
\hline 78 & Anhui & Chenyao Lake & 30.86 & 117.63 & PNR & 7.83 & 1.12 & 5.87 & 0.54 & 0.09 & 0.21 \\
\hline 79 & Jiangxi & Gushan Lake\# & 29.60 & 116.11 & UN & 7.81 & 0.18 & 0.02 & 6.23 & 0.45 & 0.93 \\
\hline 80 & Shanghai & $\begin{array}{l}\text { Chongming north } \\
\text { lake }\end{array}$ & 31.68 & 121.62 & UN & 7.73 & & & 1.44 & 0.34 & 5.95 \\
\hline 81 & Jiangxi & Zhangong Lake\# & 28.88 & 116.67 & UN & 7.26 & 7.16 & & 0.04 & 0.01 & 0.05 \\
\hline 82 & Jiangxi & Yaohu Lake & 28.71 & 116.06 & UN & 7.21 & 1.52 & 0.47 & 4.39 & 0.45 & 0.38 \\
\hline 83 & Hubei & Futou Lake & 29.99 & 114.26 & UN & 7.17 & 0.15 & 3.64 & 0.41 & 1.33 & 1.64 \\
\hline 84 & Hubei & Wuhu Lake & 30.79 & 114.47 & NR & 7.09 & 0.21 & 1.26 & 2.98 & 0.96 & 1.68 \\
\hline 85 & Shanghai & Haiwan coast & 30.83 & 121.52 & UN & 6.94 & & & 0.83 & 4.65 & 1.46 \\
\hline 86 & Jiangxi & Dahu Lake\# & 28.74 & 116.35 & UN & 6.54 & 4.76 & 1.78 & & & \\
\hline 87 & Jiangxi & Shili Lake & 29.41 & 116.01 & UN & 6.11 & 1.76 & 0.97 & 0.78 & 2.51 & 0.09 \\
\hline 88 & Hubei & $\begin{array}{l}\text { Baiji Dolphin } \\
\text { Reserve }\end{array}$ & 29.83 & 112.58 & UN & 6.00 & & & & & 6.00 \\
\hline
\end{tabular}


(Continued)

\begin{tabular}{|c|c|c|c|c|c|c|c|c|c|c|c|}
\hline \multirow[b]{2}{*}{ No. } & \multirow[b]{2}{*}{ Region } & \multirow[b]{2}{*}{ Site name } & \multirow[b]{2}{*}{$\begin{array}{l}\text { Lati- } \\
\text { tude }\end{array}$} & \multicolumn{4}{|c|}{ Feeding guilds } & \multirow[b]{2}{*}{$\begin{array}{l}\text { Grass } \\
\text { eaters }\end{array}$} & \multirow[b]{2}{*}{$\begin{array}{c}\text { Seed and } \\
\text { aquatic } \\
\text { vegetation } \\
\text { eaters } \\
\end{array}$} & \multirow[b]{2}{*}{$\begin{array}{l}\text { Inver- } \\
\text { tebrate } \\
\text { eaters }\end{array}$} & \multirow[b]{2}{*}{$\begin{array}{l}\text { Fish } \\
\text { eaters }\end{array}$} \\
\hline & & & & $\begin{array}{l}\text { Lon- } \\
\text { gitude }\end{array}$ & $\begin{array}{l}\text { Protected } \\
\text { area status }\end{array}$ & $\begin{array}{l}\text { Impor- } \\
\text { tance } \\
\text { Index }\end{array}$ & $\begin{array}{l}\text { Tuber } \\
\text { eaters }\end{array}$ & & & & \\
\hline 89 & Shanghai & Jiuduansha & 31.19 & 121.69 & NNR & 5.89 & 0.25 & & 3.16 & 1.32 & 1.16 \\
\hline 90 & Hunan & Muping Lake & 28.88 & 112.23 & PNR & 5.68 & 0.15 & 0.41 & & 0.01 & 5.11 \\
\hline 91 & Jiangxi & Daming Lake\# & 29.02 & 116.52 & UN & 4.91 & 0.84 & 3.94 & 0.04 & 0.01 & 0.08 \\
\hline 92 & Hunan & Zhongzhou & 29.02 & 112.15 & UN & 4.89 & & & 4.81 & & 0.08 \\
\hline 93 & Hubei & Shangshe Lake & 30.61 & 114.29 & NR & 4.74 & 0.02 & 3.06 & 1.07 & 0.34 & 0.25 \\
\hline 94 & Jiangsu & Longpao & 32.20 & 118.95 & UN & 4.54 & 0.03 & & 1.09 & 0.18 & 3.24 \\
\hline 95 & Jiangxi & Fanhu Lake & 28.83 & 116.07 & UN & 4.53 & & & & & 4.53 \\
\hline 96 & Anhui & Chengdong Lake & 32.33 & 116.38 & UN & 3.91 & & 1.31 & 1.60 & & 1.00 \\
\hline 97 & Jiangsu & Yangcheng Lake & 31.46 & 120.78 & UN & 3.46 & & & 2.74 & 0.06 & 0.66 \\
\hline 98 & Hubei & Changhu Lake & 30.42 & 112.40 & NR & 3.37 & & & 2.37 & 0.09 & 0.91 \\
\hline 99 & Hubei & Chidong Lake & 30.10 & 115.40 & UN & 3.17 & & & 1.28 & 0.52 & 1.37 \\
\hline 100 & Shanghai & $\begin{array}{l}\text { Chongming } \\
\text { north coast }\end{array}$ & 31.42 & 121.47 & UN & 2.97 & & & 2.22 & 0.12 & 0.63 \\
\hline 101 & Anhui & Shitang Lake & 30.43 & 116.42 & UN & 2.96 & & & 0.04 & 0.01 & 2.91 \\
\hline 102 & Anhui & Pogang Lake & 30.54 & 116.97 & PNR & 2.52 & 1.60 & 0.08 & 0.01 & 0.64 & 0.19 \\
\hline 103 & Hubei & $\begin{array}{l}\text { Huangpo- } \\
\text { huanghualao }\end{array}$ & 30.55 & 114.30 & UN & 2.47 & & & 0.83 & 0.59 & 1.05 \\
\hline 104 & Jiangxi & Nanxi Lake\# & 29.22 & 116.33 & UN & 2.33 & 1.87 & 0.10 & & 0.35 & 0.01 \\
\hline 105 & Anhui & Chengxi Lake & 32.35 & 116.20 & UN & 2.19 & & 0.99 & & & 1.20 \\
\hline 106 & Jiangxi & Yugan Xi Lake & 28.87 & 116.22 & UN & 2.16 & 2.08 & & & 0.08 & \\
\hline 107 & Hubei & $\begin{array}{l}\text { Huangmei } \\
\text { Taibai Lake }\end{array}$ & 29.96 & 115.78 & UN & 2.17 & & 0.02 & 0.77 & 0.95 & 0.43 \\
\hline 108 & Hubei & Tongjia Lake & 29.93 & 116.06 & UN & 2.03 & & 0.04 & 1.36 & 0.31 & 0.32 \\
\hline 109 & Jiangxi & Fenghuangzhou & 28.69 & 115.85 & UN & 2.02 & & & 0.04 & 1.84 & 0.14 \\
\hline 110 & Hubei & Houguan Lake & 30.51 & 113.99 & UN & 1.95 & & & 0.79 & 0.31 & 0.85 \\
\hline 111 & Jiangxi & Dahukou & 28.89 & 116.54 & UN & 1.92 & & & & 0.03 & 1.89 \\
\hline 112 & Jiangxi & Yuanyang Lake & 29.32 & 117.52 & UN & 1.90 & & & 1.82 & & 0.08 \\
\hline 113 & Jiangsu & Chishan Lake & 31.84 & 119.05 & UN & 1.88 & & & 0.51 & 0.98 & 0.39 \\
\hline 114 & Jiangxi & Wangluo Lake\# & 28.78 & 116.30 & UN & 1.70 & 1.61 & & & & 0.09 \\
\hline 115 & Jiangxi & Chouchi Lake\# & 29.24 & 116.57 & UN & 1.67 & & 1.67 & & & \\
\hline 116 & Jiangsu & Yanweigang & 34.47 & 119.78 & UN & 1.61 & & & & 0.88 & 0.73 \\
\hline 117 & Shanghai & $\begin{array}{l}\text { Changxing Is- } \\
\text { land }\end{array}$ & 31.62 & 121.50 & UN & 1.53 & & & 0.63 & 0.64 & 0.26 \\
\hline 118 & Jiangxi & Jiucai Lake\# & 29.00 & 116.65 & UN & 1.51 & & & 0.21 & 1.29 & 0.01 \\
\hline 119 & Shanghai & $\begin{array}{l}\text { Minhang } \\
\text { binjiang park }\end{array}$ & 31.01 & 121.42 & UN & 1.49 & & & & 0.05 & 1.44 \\
\hline 120 & Hunan & $\begin{array}{l}\text { Hanshou Taibai } \\
\text { Lake }\end{array}$ & 29.07 & 112.15 & UN & 1.45 & & & 1.45 & & \\
\hline 121 & Shanghai & Xinghuo Farm & 30.87 & 121.56 & UN & 1.44 & & & 0.04 & 0.79 & 0.61 \\
\hline 122 & Jiangxi & Qingshan Lake\# & 29.02 & 116.65 & UN & 1.41 & & 1.02 & 0.04 & 0.29 & 0.06 \\
\hline 123 & Jiangsu & $\begin{array}{l}\text { Dafeng Nature } \\
\text { Reserve }\end{array}$ & 33.20 & 120.46 & NNR & 1.34 & & 0.04 & 0.06 & 0.81 & 0.43 \\
\hline
\end{tabular}


(Continued)

\begin{tabular}{|c|c|c|c|c|c|c|c|c|c|c|c|}
\hline \multirow[b]{2}{*}{ No. } & \multirow[b]{2}{*}{ Region } & \multirow[b]{2}{*}{ Site name } & \multirow[b]{2}{*}{ Latitude } & \multicolumn{4}{|c|}{ Feeding guilds } & \multirow[b]{2}{*}{$\begin{array}{l}\text { Grass } \\
\text { eaters }\end{array}$} & \multirow[b]{2}{*}{$\begin{array}{c}\text { Seed and } \\
\text { aquatic } \\
\text { vegetation } \\
\text { eaters } \\
\end{array}$} & \multirow[b]{2}{*}{$\begin{array}{l}\text { Inver- } \\
\text { tebrate } \\
\text { eaters }\end{array}$} & \multirow[b]{2}{*}{$\begin{array}{c}\text { Fish } \\
\text { eaters }\end{array}$} \\
\hline & & & & $\begin{array}{l}\text { Lon- } \\
\text { gitude }\end{array}$ & $\begin{array}{l}\text { Protected } \\
\text { area } \\
\text { status }\end{array}$ & $\begin{array}{l}\text { Impor- } \\
\text { tance } \\
\text { Index }\end{array}$ & $\begin{array}{l}\text { Tuber } \\
\text { eaters }\end{array}$ & & & & \\
\hline 124 & Hubei & Xiliang Lake & 29.90 & 114.04 & UN & 1.29 & & & 0.26 & 0.26 & 0.77 \\
\hline 125 & Anhui & Wabu Lake & 32.42 & 116.88 & UN & 1.10 & & & & 1.10 & \\
\hline 126 & Anhui & Yicheng & 31.73 & 117.34 & UN & 0.98 & 0.05 & 0.02 & 0.48 & 0.31 & 0.12 \\
\hline 127 & Hubei & Tanhu Lake & 30.45 & 114.39 & UN & 0.91 & & & 0.06 & 0.45 & 0.40 \\
\hline 128 & Hunan & $\begin{array}{l}\text { Xiangjiang } \\
\text { Sides }\end{array}$ & 29.36 & 113.12 & UN & 0.82 & 0.06 & & 0.05 & 0.64 & 0.07 \\
\hline 129 & Anhui & Nvshan Lake & 32.95 & 118.07 & PNR & 0.82 & & & 0.82 & & \\
\hline 130 & Hubei & Panlongcheng & 30.64 & 114.38 & UN & 0.73 & & & 0.05 & 0.42 & 0.26 \\
\hline 131 & Hunan & $\begin{array}{l}\text { Changshax- } \\
\text { ing-cheng } \\
\text { Town }\end{array}$ & 28.68 & 111.55 & UN & 0.69 & & & 0.47 & 0.19 & 0.03 \\
\hline 132 & Jiangxi & $\begin{array}{l}\text { Xingjiang } \\
\text { River }\end{array}$ & 29.17 & 117.84 & UN & 0.67 & & & & & 0.67 \\
\hline 133 & Hubei & Jueshui River & 30.68 & 112.98 & UN & 0.43 & & & 0.04 & 0.18 & 0.21 \\
\hline 134 & Hunan & Yujiaqiao & 28.80 & 112.12 & UN & 0.26 & & & 0.08 & 0.03 & 0.15 \\
\hline 135 & Hubei & Qianjiang & 30.33 & 112.24 & UN & 0.23 & & & 0.20 & 0.01 & 0.02 \\
\hline 136 & Shanghai & $\begin{array}{l}\text { Wusongpaotai } \\
\text { Wetland }\end{array}$ & 31.27 & 121.57 & UN & 0.19 & & & 0.07 & 0.05 & 0.07 \\
\hline 137 & Jiangxi & Le'an River & 29.07 & 117.72 & UN & 0.15 & & & & 0.02 & 0.13 \\
\hline 138 & Hunan & Liyu Lake & 29.98 & 113.74 & UN & 0.13 & & & & & 0.13 \\
\hline 139 & Jiangxi & Dalei Lake & 29.10 & 116.56 & UN & 0.13 & & & & 0.09 & 0.04 \\
\hline 140 & Anhui & Zhanghu Town & 30.35 & 116.89 & UN & 0.10 & & 0.04 & & 0.02 & 0.04 \\
\hline
\end{tabular}

